\title{
Economic Organization in the Construction Industry: A Case Study of Collaborative Production under High Uncertainty
}

\author{
William A. Klein and Mitu Gulati
}

\section{INTRODUCTION}

This Article presents a case study focusing on part of the planning phase ${ }^{1}$ of a major construction project at Saint John's Hospital Center (SJHC) in Santa Monica, California. Santa Monica is a city of about 84,000 residents, ${ }^{2}$ bordered on the west by the Pacific Ocean and on the other sides by various parts of the City of Los Angeles. SJHC is a major nonprofit community hospital serving Santa Monica and the west side of Los Angeles. ${ }^{3}$

- Respectively, Maxwell Professor of Law Emeritus, UCLA School of Law, and Professor of Law, Georgetown University Law Center. The authors are grateful to Robert $O$. Klein for allowing William Klein (no relation) to observe the planning process at Saint John's Health Center described in this Article. Robert Klein also generously provided information and ideas, as did other SJHC representatives, especially A. Redmond Doms and Michael P. Russell. Also generous with their time and valuable for their ideas were the various members of the Master Site Planning Team (identified in this Article), especially Paul Danna and Dana Taylor. In various conversations over the years, Joseph J. Scarano provided many important insights into the construction industry in general. Other valued sources of information and ideas were David Forbes Hibbert and Joan Ling. Among our colleagues at UCLA, Stephen M. Bainbridge was, as always, an invaluable listener, critic, and supporter, as was Lynn Stout. For their insights into motion picture production we are grateful to David R. Ginsburg and Kenneth Ziffren and for their insights into law firms we are grateful to Joel Rabinovitz and Stephen C. Yeazell. For comments and conversations about prior drafts we are grateful to Scott Baker, John Borchenheimer, George Dent, Tom Geu, Lynn LoPucki, Gail Pesyna, Larry Ribstein, Steve Salop, and participants in the symposium on "The Role of Law in Promoting Long-term Value for Public Shareholders," sponsored by the Berkeley Business Law Journal and the Mercatus Center (2003), and at a workshop at UCLA.

Note on the Interviews and Project Documents: At various points in this Article, we refer to interviews and documents relating to the construction project that is the subject of this case study. In order to ensure verifiability for later researchers, we have disclosed the names of the interviewees and the documents in question. The specific documents and interview notes are on file with the authors.

1. The general planning process of which this planning project is a part has been a long-term effort involving many people, yet the planning that is the focus of the present study is itself a substantial project, with a budget of about $\$ 1$ million.

2. The population declined from 88,314 in 1980 to 84,084 in 2000 . See City of Santa Monica, Demographic \& Economic Profile: Population and Race/Ethnicity (relying on the 2000 Census), at http://pen.ci.santa-monica.ca.us/resource_mgmt/demographics/pop_race2.htm (last visited Dec. 2, 2002). In 2000 the Santa Monica population was 72 percent white, 13 percent Latino, 7 percent Asian/Pacific, and 4 percent African American. SJHC, with 1,755 employees, was the second largest employer in the City, close to the City's 1,892 employees. Id. There were 6,028 firms, which provided 74,077 jobs; this helps explain the traffic problems that were a significant issue for $\mathrm{SJHC}$ in seeking approval of its development plans. Id.

3. According to a SJHC planning document, the SJHC "primary service area is marked by a relatively affluent, aging population, with no expectation of significant population growth." SJHC 
The goal of this study is to gain insight into some of the key attributes of the microsystem that assembles inputs and organizes large-scale, complex production without central planning.

\section{BACKGROUND: Why CONSTRUCTION PROVIDES VALUABLE INSIGHTS}

Legal and economic scholars have devoted little attention to an industryconstruction-that seems to offer valuable lessons about the organization of economic activity. ${ }^{4}$ Major construction projects are generally initiated, and proceed, without governmental central planning, without organized, formal markets for the exchange of services, and without hierarchical top-down control within a single firm. ${ }^{5}$ Many of the characteristics that have long been associated with the construction industry are now increasingly observed in outsourcing by traditional firms and, by the extension of that process, in the virtual firm. ${ }^{6}$ Construction projects reflect a system of economic organization involving a high degree of contracting, both formal and informal, rather than formal integration. This contracting may take place under conditions of high uncertainty; conditions may be constantly changing and ex ante specification of rights and obligations is often difficult at best. Construction projects also

Strategic Vision Statement (undated) (on file with authors). At the same time, according to a presentation by one of the feasibility consultants (The Camden Group), that W. Klein attended, national health care spending was expected to increase by about 50 percent from 2001 to 2007.

4. See, e.g., STUART H. Bartholomew, Construction Contracting: Business and Legal PRINCIPLES (2001) (providing a general description of the industry); GERALD FINKEL, THE ECONOMICS OF THE CONSTRUCTION INDUSTRY (1997) (same); JUSTIN SWEET, LEGAL ASPECTS OF ARCHITECTURE, ENGINEERING AND THE CONSTRUCTION PROCESS A-1 to I-48 (6th ed. 2000) (same).

5. Not all of these characteristics apply to all construction projects. In fact, it is somewhat misleading to refer generically to a construction industry, since there is wide variation in types of projects, including highway construction, single-family residential tract development, apartment building construction, etc. Each has its own particular organizational structure and modes of operation. In highway constnuction, for example, traffic disruption is a major problem and specialized types of contract provisions have been developed to provide appropriate incentives to minimize the disruption. See Zohar J. Herbsman et al., Time Is Money: Innovative Contracting Methods in Highway Construction, $121 \mathrm{~J}$. CONSTRUCTION ENGINEERING \& MGMT. 273 (1995). Moreover, it is often said that "all construction is local," and there are important regional differences-for example, differences in the role of trade unions. The segment of the industry that is the focus of the present study is the development of large commercial and multi-use projects in Southem California. It does seem, however, that many, perhaps most, of the observations and insights offered here are applicable to other types of construction in other parts of the country, and, in any event, are instructive for the case-study's basic inquiry into the nature of economic organization.

6. See Tim Jackson, Virtual Corporation with a Twist, FIN. TIMES, Feb. 5, 1996, at 11 (describing an information-technology firm that limits its function to its "two core competencies: developing innovative engineering solutions and signing deals with powerful marketing partners around the world" and outsourcing all else); Roderick M. Kramer \& Tom R. Tyler, Wither Trust, in TRUST IN ORGANIZATIONS 8 (Roderick M. Kramer \& Tom R. Tyler, eds., 1996) ("Organizations are moving away from formal hierarchical structures to more flexible and temporary groupings around particular projects."); Robert J. Laubacher et al., Two Scenarios for 2 Ist Century Organizations: Shifting Networks of Small Firms or All-Encompassing "Virtual Countries"? (1997) (working paper), available at http://ccs.mit.edu/21c/21CWP001.html (last visited Dec. 20, 2002). See also ANNA LEE SAXENIAN, Regional adVANTAGe: Culture and COMPETITION IN Sillicon Valley and ROUTE 128 (1996) (describing organizational structures in Silicon Valley and Route 128); DANIEL F. SPULBER, THE MARKET MAKERS, Chs. 5, 6 (1998) (describing the flattening of organizational hierarchies). 
provide insights into the role of teams of individuals from different firms; into the networks of relationships that produce such teams; into a "culture of collaboration"? that seems vital to successful teamwork; into trust, reputation, and other such informal, nonlegal mechanisms that affect collaboration; and, in a minor way in this study, into the role of written contracts.

It seems useful to expand briefly on these ideas.

As has just been suggested, the types of major construction projects of which the $\mathrm{SJHC}$ project is a good example are accomplished by the creation of a team of legally independent individuals or firms. The construction team ${ }^{8}$ has been described as a "quasi-firm," which means that it (and its counterpart, the virtual firm) is not a firm at all. Rather, it is a network of relationships and contracts. ${ }^{10}$ Most notably, it lacks the characteristic of hierarchical control. The

7. The importance of collaboration was first brought to co-author Klein's attention by Joseph Scarano, an architect who specializes in construction management, as director of the Los Angeles office of 3D/international. See 3D/l website, at http://www.3DI.com (last visited Mar. 1, 2004). Its importance has been uniformly confirmed in conversations with other people involved in construction. The culture of collaboration may be contrasted with the culture of command associated with the strongly hierarchical organization that characterizes large-scale, vertically and horizontally integrated industrial production. However, "[i]n the late twentieth century, the face of manufacturing is changing," with a great deal more flexibility. Paul Milgrom \& John Roberts, The Economics of Modern Manufacturing: Technology, Strategy, and Organization, 80 AM. ECON. REV. 511 (1990). This leads, on one hand, to integration and, on the other hand, to "an extensive use of independently owned suppliers linked with the buying firm by close communication and joint planning." Id. at 526 .

8. There is substantial scholarly literature on teams and teamwork. Its focus is mostly on teamwork as a way of increasing productivity and efficiency within an existing, larger organization. See, e.g., Stephen M. Bainbridge, Director Primacy: The Means and Ends of Corporate Governance, 97 Nw. U. L. REV. 594-96 (2003). In the present study, the team is the organization. That is, teamwork not only enhances productivity but also provides the organizational structure. In any event, the literature on teams and teamwork, while obviously relevant to the present study, does not seem to bear directly on the issues that are the principal focus of this study. For a study of the types of teams that are more similar to those in construction (e.g., TV programs and theater productions), though shorter term and smaller in scope, see Debra Myerson et al., Swift Trust and Temporany Groups, in TRUST IN ORGANIZATIONS, supra note 6 , at 166 . The following statement from that study seems relevant to this one: "[A]s the size of the pool from which members are selected gets smaller, talent becomes thinner, and information about performance diffuses more effectively, then reputations become vulnerable" Id. at 171 . The vulnerability of reputations is then said to lead to the development of trust. Id. at 181 .

9. Robert G. Eccles, The Quasifirm in the Construction Industry, 2 J. ECON. BEHAV. \& ORG. 331$57(1981)$

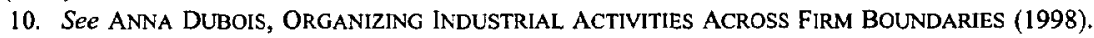
The point is that it is neither the firm nor a system of markets that is the proper focus, but rather networks of dyadic relationships. "Interdependence ... blurs the firm boundaries and thus makes individual make-or-buy situations difficult to delimit." Id. at 2. "The dichotomy between firm and market, between directed and spontaneous co-ordination, is misleading; it ignores the institutional fact of co-operation and assumes away the distinct method of co-ordination that this can provide." Id. at 14 (quoting G.B. Richardson, The Organization of Industry, THE ECON. J., 883, 895 (1972)). The present study adds the additional reality that the network of relationships is primarily among individual members of firms and only secondarily among the firms of which they are members. See infra Part VII.B.

A prime example of extensive outsourcing and the collaboration that it requires among independent contractors is found in the Japanese automobile industry, in which a company such as Toyota is essentially an assembler, working cooperatively with the suppliers of virtually all of its components. DuBois at 7. See also DUNCAN J. WATTS, SIX DEGREES: THE SCIENCE OF A CONNECTED AGE 254-60 (2003) (describing the cooperation among Toyota's many independent suppliers to fill a supply gap, with almost unbelievable speed, when the factory of the single supplier of a vital component was 
architects, engineers, consultants (e.g., acoustical, landscape, roofing, interiors, structural), general contractors, trade contractors (e.g., electrical, plumbing, specialty concrete, drywall), and suppliers (e.g., air conditioning unit, elevators, steel, windows) are all legally independent contractors, not employees. They do not work exclusively for the owner/client and are not, legally, people "whose physical conduct in the performance of the service is controlled or is subject to the right of control by the [owner/client]." At the same time, the legal and practical independence of the participants in construction projects elevates the importance of collaboration.

The focus of much of legal and economic scholarship is on dyadic relationships and bilateral contracts. Construction projects draw attention to the mosaic of which dyadic relationships are a part. From an economic or practical perspective, no contract stands alone, and the terms of each contract must take account, at least implicitly and in a general way, of the terms of others, because the work efforts of the various contractors are interdependent. ${ }^{12}$ The

destroyed by fire); Toshihiro Nishiguchi \& Alexandre Beaudet, Fractal Design: Self-organizing Links in Supply Chain Management, Ch. 7, in KNOWLEDGE CREATION, A SOURCE OF VALUE (Georg von Krogh et al., eds., 2000) (offering a more detailed description of the same event); J. Mark Ramseyer, Rethinking Relationship-Specific Investments: Subcontracting in the Japanese Automobile Industry, 98 MiCH. L. REV. 2636 (2000) (presenting general statistics with some focus on Honda). The Japanese automobile industry is also discussed in Bengt Holmstrom \& John Roberts, The Boundaries of the Firm Revisited, 12 J. ECON. PERSP. 73, 80-83 (1998). Holmstrom and Roberts observe that "there seems to be something of a trend today toward disintegration, outsourcing, contracting out, and dealing through the market rather bringing everything under the umbrella of the organization." $I d$. at 80 . Later the authors claim that "[t]he key to making this system work is obviously the long-term, repeated nature of the interaction." $I d$. at 82 . That is also a characteristic of the construction industry but to a lesser degree and only if one thinks of the industry as a whole and thinks of a succession of projects-quite often with different clients-rather than a single project. The central focus of the Holmstrom and Roberts article, however, remains the dichotomy between firms and markets and the various explanations of the function of each.

For another take on Toyota and the Japanese automobile industry, see PAUL MILGROM \& JOHN ROBERTS, ECONOMICS, ORGANIZATION \& MANAGEMENT 4-6, 565-69 (1992); OLIVER E. WILLIAMSON, THE ECONOMIC INSTITUTIONS OF CAPITALISM 120-21 (1985). The system in the Japanese automobile industry has in recent years been adopted to some substantial degree in the United States and elsewhere. See Curtis R. Taylor \& Steven N. Wiggins, Competition or Compensation: Supplier Incentives Under the American and Japanese Subcontracting Systems, 87 AM. ECON. REV. 598, 600 (1997); Will the Corporation Survive? in The Next Society: A Survey of the Near Future, THE ECONOMIST, Nov. 3, 2001, at 14-18 (special section following page 54). Another example of extensive outsourcing is "Sony Corp.'s TV plant in Mount Pleasant, Pa., [which] has developed a network of more than 1,300 vendors within the three area codes surrounding the plant. ..."Clare Ansberry, The Outlook: Mantufacturers Find Themselves Increasingly in the Service Sector, WALL ST. J., Feb. 10, 2003, at A2.

Consider also the examination of the make-or-buy decision (another way of stating firm versus market or in-house production versus outsourcing), in the aerospace industry, in Scott E. Masten, The Organization of Production: Evidence from the Aerospace Industry, 27 J. LAW \& ECON. 403 (1984).

See also George W. Dent, Jr., Gap Fillers and Fiduciary Duties in Strategic Alliances, 57, 58 THE BUS. LAWYER 55 (2001) ("Strategic alliances pose a paradox: under classic financial theory they should not exist. In theory, business is transacted either in markets or in firms; a firm chooses to 'make-or-buy' each input it needs. Strategic alliances fit neither category.").

11. RESTATEMENT (SECOND) OF AGENCY \& 2(2) (1958).

12. The Chinese metaphorical perspective, stated by Fei Xiaotong, seems apt:

The Chinese pattern of social organization is like the circles that appear on the surface of a lake when a rock is thrown into it. Everyone stands at the center of the circles produced by his or her own social influence. Everyone's circles are interrelated. One touches different circles 
multilateral nature of relationships is important to bear in mind because it affects and limits incentives and the allocation of control. ${ }^{13}$

But there is something far more fundamental than this at work-a phenomenon that may be referred to, as previously suggested, by the phrase "culture of collaboration." A construction project requires teamwork and a willingness and ability to adjust to changing needs and circumstances without hierarchical control. ${ }^{14}$ Construction plans can never specify all details or anticipate all contingencies. Even after the architects and engineers and their consultants have completed their construction drawings and specifications and the contract for construction has been signed, the general contractor and subcontractors will need to provide "shop drawings: the final fabrication drawings for building systems." 15 And even then, it is likely that unanticipated problems will arise and the team members (including the architect, engineer, general contractor, subcontractors, and suppliers of components) will need to work together to devise the solutions. ${ }^{16} \mathrm{~A}$ change agreed upon by the general

at different times and places.

From the SOIL: Foundations of ChINESE Society as Viewed by FeI Xiaotong 28 (Gary Hamilton \& Wang Zheng trans. 1992), quoted in Lucie Cheng \& Arthur Rosett, Contract with a Chinese Face: Socially Embedded Factors in the Transformation from Hierarchy to Market, 1978-1989, 5 J. CHINESE L. 143, 216 (1991).

See also D.K.H. Chua et al., Critical Success Factors for Different Project Objectives, 125 J. CONSTRUCTION ENGINEERING \& MGMT. 142 (1999) (offering several diagrams that nicely illustrate this complexity and interrelatedness).

13. See Holmstrom \& Roberts, supra note 10, at 92 ("In market networks, interdependencies are more than bilateral, and how one organizes one set of transactions depends on how the other transactions are set up."). This observation is a minor point, however, in this Article, which takes as given the importance of the firm-versus-market dichotomy.

14. Compare the following statement in the Government's request for proposals for the reconstruction of the Pentagon:

The Contractor and the Government will form a unified, collocated team that will jointly manage project activities as described in this document. Both parties, to the greatest degree practical, will adapt their processes whenever appropriate to provide for common processes within the unified teams. The team is jointly responsible for solving all problems that arise.

Public Release Version of the Pentagon Renovation Wedges 2-5 Request for Proposal 5 (2001) (on file with authors).

The Government further states:

Given the tremendous control that the Contractor exercises over the budget for this project, the

Government will consider the relationship between the parties fundamentally flawed if either has to resort to a near-continuous stream of relatively small dollar change requests or orders to realize progress. Id. at 4.

15. 3D/International, Project Delivery Strategy 2 (unpublished essays), available at http://www.3di.com (available only on Internet Explorer, not Netscape) (last visited Jan. 14, 2003).

16. As Joseph Scarano put it during one of our interviews with him, "You never get a perfect set of documents because there are so many variables." The problems arising from unanticipated conditions are particularly acute on new construction in the below-ground work because of the uncertainty of the conditions and in renovation because of the uncertainty of what lies beyond the walls. Even on new construction above the ground, however, there may arise problems that, in a perfect world, would have been anticipated but in the real world were not. For example, suppose that there has been inadequate foresight on the relationship between the steel beams and the air ducts and the design calls for an air duct to go through a steel beam in a way that would compromise the beam's integrity. Members of the construction team will need to collaborate to find a solution. 
contractor and, say, the plumbing contractor, or a delay in performance by that contractor, may require adjustment by various other subcontractors either as to what they do or when they do it or both. ${ }^{17}$ This phenomenon of collaboration seems to trivialize (at least in this context) the distinction between firms and markets and between separable and nonseparable tasks. ${ }^{18}$ It is true, to be sure, that in the end there is one person or entity that has the legal, and perhaps even the practical, right to exercise control- - to decide by fiat. But the premise of this study is that there is much to be learned from a focus on complexity, on networks, and on collaboration, as contrasted with hierarchy and fiat, and that this focus may provide useful insights into the distinction between firms and markets. The focus on complexity, networks, and collaboration need not deny that there is a nexus for the relationships. Nor need it, or does it, deny that there is a set of bilateral contracts, between or among several key participantsgenerally, contracts with the client or the general contractor. Moreover, in the project examined in this study, the client's representatives are actively involved in the project on a day-to-day basis, and there is no doubt about who is ultimately calling the shots. But the existence of a nexus and of dyadic relationships (between the client and the various contractors) is not what makes the construction industry especially interesting.

Construction projects may seem to have unique characteristics that limit their relevance to other economic activities. ${ }^{19}$ To be sure, in the construction industry the principal organizing devices are contract (outsourcing) and

On any sizable project, there is likely to be a regularly scheduled weekly meeting of representatives of the design team (the architect, the structural engineer, and the mechanical engineer), the general contractor, the construction manager, and the major subcontractors, to iron out problems. $C f$. Stewart Macaulay, Non-Contractual Relations in Business: A Preliminary Study, 28 AM. SoC. REV. 55 (1963). The distinction between our focus and Macaulay's in his outstanding article is that his focus was on the dyadic relationships alone and not on the network of such relationships. Given a network of contractual relationships, participants need to take account of how accommodation of one participant may require the cooperation of others. This in turn draws attention to the importance of teamwork and collaboration. What matters to both Macaulay and to the present inquiry is the significance of informal mechanisms for enhancing cooperation and accommodation. See DUBOIS, supra note 10, at 16.

17. The same process in connection with the manufacture of trucks by the Swedish company, SweWork, is described in detail in DuboIS, supra note 10, at 37-91. See also supra note 10 (describing the Japanese automobile industry).

18. Note, however, that within a project team there may be two or more people from a single firm; these individuals have a firm-sourced relationship as well as a team relationship. Moreover, the contributions of the individual members from, say, a firm of architects may be less separable than the contributions of the architects and the general contractor.

19. Construction has been treated as an example of "temporary systems ... defined as a set of diversely skilled people working jointly on a task of some complexity over a limited time period."

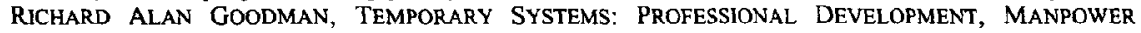
UTILIZATION, TASK EFFECTIVENESS, AND INNOVATION 2 (1981). Goodman claims that "[t]he most prominent [temporary system] in the modern era is the research and development project," but also includes "presidential commissions and senate select committees" as well as "theatre, construction, auditing teams, architectural groups, negotiating teams, juries, election campaign organizations, etc." $I d$. at 4. As previously suggested (see supra notes 9-10), however, such systems have much in common with the phenomenon known as outsourcing and, even more clearly, with the virtual firm, which is simply an extreme form of outsourcing. 
collaboration rather than the hierarchy and command that characterize much of large-scale industrial production and many segments of the service industries, but contract and collaboration are important in aspects of all economic organization and increasingly so in recent times. Additionally, the notion of control that is so vital to the concept of the firm is far more slippery than discussions of firms generally recognized. ${ }^{20}$ In a firm such as General Motors, for example, there is important hierarchical organization, but control of workers is constrained by, among other considerations, union power, while control over executives is constrained by their opportunities to move to other firms. Moreover, General Motors must contract and collaborate with its many suppliers, as well as with its dealers. Construction may seem unique in that projects are finite and are characterized by a high degree of uncertainty. But the same characteristics are found in the entertainment industry, in the delivery of legal services, and in most other industries, such as automobile production, though perhaps less dramatically so. Furthermore, in construction, though the identity of the participants will generally change from project to project, the industry persists and the participants are in for the long haul, which, of course, affects how people behave on any particular project. Once one adopts an industry-wide perspective, one can recognize the importance of the continuing nature of interaction. ${ }^{21}$

\section{The Saint John's Health Center Project}

\section{A. The Hospital: History, Needs, and Plans}

Saint John's Health Center (SJHC), as previously noted, is a major community hospital. In 2002 the AARP ranked SJHC twelfth among the top fifty hospitals in the country. ${ }^{22}$ It is affiliated with the renowned John Wayne Cancer Institute, ${ }^{23}$ which is located next to the SJHC hospital complex.

20. Rock and Wachter claim that reference to general contractors as examples of nexus of contract as that term is used in corporate-law theory is "misleading . . . about firms in general." Edward B. Rock \& Michael L. Wachter, Islands of Conscious Power: Law, Norms, and the Self-Governing Corporation, 149 U. PA. L. REV. 1619, 1628, n.12 (2001). This claim (a minor observation in an otherwise insightful and valuable article) is typical of much writing about firms in that it assumes what is at issue-that the word "firm" has a well-defined and useful meaning. That assumption must depend in turn on the assumption-questionable at best-that in general, in business organizations, there is a common and identifiable model of hierarchical control, with dominating employers and compliant employees. If the firm is defined in terms of a residual right of control, as under the property-rights theory of the firm (see $i d$. at 1634), then it would seem that a construction project is a firm, with the owner/client as quasiemployer and all others as quasi-employees. But then the concept of a firm becomes all-inclusive, so as to be almost useless.

21. See Holmstrom \& Roberts, supra note 10 , at 81 .

22. See AARP Magazine On-line, at http:/www.modernmaturity.org/departments/2002/ health/chart.html (last visited Dec. 19, 2002). SJHC's two major competitors were ranked second (Cedars-Sinai Medical Center) and ninth (UCLA Medical Center).

23. See John Wayne Cancer Institute Website, at http://www.jwci.org (last visited Mar. 1, 2004). 
SJHC was founded in 1942 by the Sisters of Charity of Leavenworth (SCL). ${ }^{24}$ The SCL have their headquarters in Leavenworth, Kansas and, through a corporation entitled Sisters of Charity of Leavenworth Health Systems (SCLHS), control a total of nine hospitals and four stand-alone clinics in four western states, California, Colorado, Kansas, and Montana. SJHC is the most successful of the hospitals. While SJHC has considerable autonomy, its major decisions are subject to the veto power of the board of SCLHS. ${ }^{25}$

In January 1994 a major earthquake ${ }^{26}$ severely damaged the main hospital building of $\mathrm{SJHC}$, forcing closure of that building for about eight months. Repairs were made that allowed the hospital to resume operations on an interim basis ${ }^{27}$ but bringing the fifty-year-old building into compliance with current earthquake standards was another matter. ${ }^{28}$ Moreover, new facilities were thought to be necessary to deal with changes in health care technology and systems of delivery and to provide "extended services which focus on outpatient care, prevention and community health education. ${ }^{29}$ A decision was arrived at, therefore, that it would be best to replace the existing building with a new one. Thus began an extensive planning process that went beyond simply replacing the existing facilities and sought to imagine and provide for ancillary needs in the immediate and the more distant future. Some or all of the ancillary needs-including a large parking structure and a medical office building-may be essential to the continued success of the core hospital operation. The resulting project's complexity and cost were increased substantially by staging problems - that is, by the need to construct large new buildings on much the same site occupied by the existing buildings. The focus of this study is on the planning for the ancillary needs and the integration of the ancillary facilities with the core hospital facilities in an enlarged and visually attractive campus extending beyond the boundaries of the original campus.

The overall planning process had led, in 1998, to a development agreement with the City of Santa Monica. This was a lengthy, detailed agreement that was

24. See CSL Website, at http://www.scls.org (last visited Dec. 2, 2002); Health System Website, at http://www.sclhs.info/default2.htm (last visited Dec. 2, 2002).

25. What is perhaps even more important in the present context is that SJHC not only requires approval from SCLHS for major projects but also must rely on SCLHS for a large amount of the funding for its major capital investments, at least in the short run (that is, at least for interim financing).

26. This was the so-called Northridge earthquake. Its epicenter was about twenty miles north of SJHC, but because of the peculiarities of the earthquake and of the soil conditions in Santa Monica, it inflicted substantial damage in Santa Monica, while sparing much of the intermediate and surrounding areas. The same earthquake also damaged the UCLA hospital (about ten miles to the northwest of SJHC) and led to a decision to replace that hospital's main structure. For both hospitals, much of the money needed for the new construction has come from the Federal Emergency Management Agency (FEMA).

27. It was necessary, however, to demolish part of the hospital facilities (the North Wing).

28. The new state-mandated earthquake standards reflected the special need, following any future earthquake, for hospitals that would be able to provide emergency care.

29. Project Development Agreement at 7 (on file with authors) [hereinafter Development Agreement]. 
effective until 2008. The main function of such an agreement is to provide the developer of a major, long-term, multi-stage project with a commitment by the City to allow construction of the structures described in the agreement-that is, a commitment not to change the rules, ${ }^{30}$ while at the same time "preserv[ing] substantial City discretion in reviewing subsequent developments." 31 The individual structures would still require approval for compliance with various engineering, architectural, safety, and other provisions. The development agreement divided the plans into two phases. Phase I covered primarily the core hospital buildings (with patient beds, operating rooms, laboratories, etc.) in a three-square-block area north of a major east-west artery, Santa Monica Boulevard-the area called the "north campus." This location lies within a built-up section of the city that includes both commercial and residential properties. The development agreement for Phase I reflects the City's concerns with a variety of issues, ${ }^{32}$ not the least of which is traffic and parking. At the time the present study was initiated, the construction on Phase I was well underway, though still (at the end of 2002) a long way from completion.

Phase II is the object of the current study. It contemplates some significant changes on the north campus, but is concerned largely with development of the "south campus"-a three-square-block area south of Santa Monica Boulevard, where SJHC owns several parcels of property and was considering acquisition

30. California law declares that:

Assurance to the applicant for a development project that upon approval of the project, the applicant may proceed with the project in accordance with existing policies, rules and regulations, and subject to conditions of approval, will strengthen the public planning process, encourage private participation in comprehensive planning, and reduce the economic costs of development.

CAL. GOV'T. CODE $§ 65864(\mathrm{~b})$. Section 65865.2 provides:

A development agreement shall specify the duration of the agreement, the permitted uses of the property, the density or intensity of use, the maximum height and size of proposed buildings, and provisions for reservation or dedication of land for public purposes. The development agreement may include conditions, terms, restrictions, and requirements for subsequent discretionary actions, provided that such conditions, terms, restrictions, and requirements for subsequent discretionary actions shall not prevent development of the land for the uses and to the density or intensity of development set forth in the agreement. The agreement may provide that construction shall be commenced within a specified time and that the project or any phase thereof be completed within a specified time.

The agreement may also include terms and conditions relating to applicant financing of necessary public facilities and subsequent reimbursement over time.

31. Development Agreement at 7.

32. The development agreement covers such obvious matters as total permissible square footage, as well as items such as landscaping, drainage, etc. The main new structures on the north campus were to be for "Inpatient Suites," a "Diagnostic and Treatment Center," and a "New Central Plant." Development Agreement at 44. The development agreement also provides for a "plaza area [to] serve as the principal vehicular and pedestrian entrance and exit," for subterranean parking (id.) and for a "North Lawn" of 41,300 square feet, "to provide a serene outdoor location for recuperating patients," but open to the public (id.). To preserve the serenity, however, there are restrictions on types of public use, including a prohibition on "cooking, dispensing or preparing food, ... sleeping camping, or staying overnight," a nontrivial restriction given Santa Monica's welcoming, or at least tolerant, treatment of homeless people. $1 d$. at $44,58-61$. 
of additional parcels. ${ }^{33}$ Currently, the John Wayne Cancer Institute is located on the south campus. One part of the Phase II project is a new location or set of locations for that Institute (which needs space both for patient care and for research laboratories). Other possible buildings on the south campus would include a medical office building, a health and fitness center, ${ }^{34}$ residential housing with some units for nurses and doctors, assisted-living housing, an education and conference center, and, possibly, some town houses, a restaurant, and a small retail space. All of this would require substantial additional parking in above- and below-ground structures-which turned out to be a first priority, especially because there is an existing parking deficit on the north campus. More vitally, all of it was subject to uncertainty because of questions of market demand and availability of financing. Further difficulty arose from the need to move quickly. To be successful, hospitals need patients, and patients are brought in by doctors. Consequently, SJHC must keep the doctors happy, and this requires good hospital facilities (operating rooms, diagnostic laboratory services, hospital beds, and outpatient and ambulatory amenities), and good nearby office space. ${ }^{35}$ There was a serious concern that if SJHC did not move quickly to fill, or at least demonstrate its commitment to fill, these needs, the needs would be filled by other area hospitals ${ }^{36}$ or by new, private-sector offerings (such as office buildings with outpatient operating facilities.) There was also one other important objective: to provide visual improvements (landscaping, walkways, etc.) that would integrate the north and south campuses and enhance the appeal of the entire campus. ${ }^{37}$ With all this in mind, SJHC obtained U.S. \$1 million to engage in planning for Phase II (but coordinated with Phase I). ${ }^{38}$

33. The three-square-block areas north and south of Santa Monica Boulevard run three blocks east and west and one block north or south, so the two areas share a three-block-long frontage on Santa Monica Boulevard. The entire north campus area is owned by SJHC, but two medical office buildings on the westem border ( 20 th Street) are owned by other investors on ground leased from SJHC.

34. This was to include not only the usual fitness center equipment and facilities but also therapy pools, cardiac rehabilitation, and physical therapy areas, etc. Its target is not the young and fit people who populate typical health clubs (which were in ample supply in the area) but rather the "unconditioned" population and people in need of the services of trained professionals.

35. Surgeons don't want to waste their valuable time going from their offices to their operating rooms and surgeons are vital to a hospital's financial success.

36. SJHC serves the relatively affluent west side of Los Angeles, but it has at least two major competitors, one of which (the expanding Santa Monica branch of the UCLA hospital) is about half a mile away.

37. The Phase I plan had already provided for an entrance plaza on the north side of Santa Monica Boulevard, and the Phase II landscape/visual plan needed to be integrated with this in some way.

38. In 1995, SJHC had received a $\$ 10$ million grant from the Keck Foundation to plan a model health center for the twenty-first century. The vision for the south campus, though not a primary focus, arose in large part from that planning effort. SJHC used its own funds for the Phase II master site planning that was initiated in 2002 and is the focus of this Article. 


\section{B. Organizational Structure of SJHC}

The key figure at SJHC in planning for Phase II is Robert O. ("Bob") Klein, ${ }^{39}$ a vice-president of SJHC who was appointed director of that project. ${ }^{40}$ Another key figure is A. Redmond ("Rusty") Doms, who served without pay as President of the SJHC Foundation (principally responsible for fundraising and finance) and played an active role in the planning process. ${ }^{41}$

The SJHC CEO is Bruce Lamoureux, a highly regarded hospital executive, who was always well informed of what was happening in the planning process, but was not an active participant. SJHC has a thirteen-member board of directors, which includes doctors, a hospital administrator, and several successful real estate developers. The SJHC staff and its board of directors have considerable autonomy, but at the top of the formal decision-making chain is the Board of Directors of SCLHS, ${ }^{42}$ which, among other powers, appoints the CEO of SJHC.

Perhaps of most relevance for the purposes of this study is that Klein and Doms were able to draw on the input of knowledgeable and experienced people in the community, particularly people on the Foundation's seventy-five-person board of trustees and on the SJHC board of directors. Klein and Doms also established an advisory Master Site Planning Committee of fifteen people, including several prominent and successful real estate developers, the chief of the SJHC medical staff, and certain key SJHC executives.

\section{The City of Santa Monica}

Until the mid 1970s, Santa Monica's City Council was largely controlled by conservative local business owners, landlords, and small-time developers, along with some community activists and long-time residents. At that time, however, housing prices, and rents, began to rise. A substantial majority of the population of Santa Monica lived in rental units (still true). The renters supported a renter's rights organization, which took control of the City Council. As a result, Santa Monica became one of those communities sometimes referred to as "the people's republic of . . .,43 Rent control was imposed. More

39. No relation to, but a long-term friend of, co-author W. Klein, Bob Klein made it possible for W. Klein to observe the planning process.

40. Klein's position was, and remained, vice president of the SJHC Foundation, the branch of SJHC responsible for fund raising. Klein, however, had a background in real estate development and in addition to his fund-raising work had, over the years, represented SJHC in a variety of its real estate dealings.

41. Doms was also the chair of the SJHC building committee and head of the master site planning committee.

42. In the interests of brevity and in an effort to avoid confusion in conversation, SCLHS is sometimes referred to as "Leavenworth."

43. A column in the Los Angeles Times on October 16, 2002, begins with this quotation from a 1982 segment of "60 Minutes": "The radicals . . . haven't renamed Santa Monica 'Ho Chi Minh City, but if they did, the people who used to rule here-the conservatives, the landlords, the developers, the 
to the point for present purposes, the City adopted various provisions that have made development difficult and costly. Among many other requirements, the City boasts of "a set of guidelines to facilitate development of 'green' buildings" and of having two building code ordinances that, "aim at higher environmental and resource performance of buildings than state or federal requirements." 44 Builders must, as in most other cities, comply with myriad building-code, zoning, and other requirements and satisfy an array of City bureaucracies. ${ }^{45}$ Beyond that, they must take account of the positions of various special- or public-interest groups that may be able to convince the City Council to kill, or impose additional requirements on, a project. ${ }^{46}$ Moreover, while there are many individuals and groups within the community who support affordable housing, there is also strong anti-growth and anti-development sentiment, to which members of the Council must respond. This being so, an important criterion for selection of consultants and contractors for the SJHC master site plan was knowledge of how to comply with the rules and get things done in Santa Monica. In a sense, the administrators, politicians, and citizens of Santa Monica were silent but influential members of the planning team. ${ }^{47}$

\section{The Master Site PlanNING TEAM AND ITS MisSION}

The major focus of this study is on the process of creating a master site plan. The observations reported here begin with the initial formation of a Master Site Planning Team (MSPT), which is distinguished from the Master

business people-wouldn't be at all surprised." Anne-Marie O'Connor, Sea Change in Santa Monica, L.A. TIMES, Oct. 16, 2002, at Al. The article notes a change in the politics as the population became wealthier. "Nowadays, Santa Monica seems more like Beverly Hills run by the Green Party." Id.

44. See Santa Monica Green Building Program Website, at http:/greenbuildings.santa-monica.org (last visited Mar. 1, 2004). The ordinances include detailed recommendations (ignored at one's peril) for landscaping, with the objective of reducing energy and water use, as well as the use of fertilizers, pesticides, and herbicides.

45. A building project like that of SJHC requires the approval of City offices responsible for planning, building and safety, traffic, zoning, transportation management, fire, trees and landscaping, environmental matters, etc.-all of which are subsidiary to the Planning and Community Development Department, whose recommendation is reviewed by the Planning Commission and is also subject to review by the Architectural Review Board and the Landmarks Commission. Approval of any major project by the Planning Commission is difficult, at best, to achieve. The Planning Commission decision can be appealed to the City Council, which is highly sensitive to political issues raised by development projects. The entire process is likely to take at least twelve months and generally will take eighteen months or longer.

46. Moreover, according to Mike Russell, it is not unusual for a developer, after eighteen months or more of costly planning, and gaining approvals from overlapping jurisdictions (federal, state, local, and regional), to find its project held up by a lawsuit that anyone can file for $\$ 200$.

47. SJHC is a valuable community resource, supported in large part by substantial donations. Moreover, it has long provided public services, including support for the Venice Clinic (in a part of Los Angeles contiguous with Santa Monica) and operation of a highly praised Child and Family Center. Nonetheless, as a condition for receiving the right to build the new hospital (costing over $\$ 100$ million for the first building alone), it was required to provide free services to the community for the benefit of school children, and for "the indigent; uninsured and under-insured, seniors and persons with disabilities; women; and the homeless." Development Agreement at 20-21. These services must have an annual value of at least $\$ 732,000$, rising by 1.5 percent per year, for fifty years. $I d$. at 25 . 
Site Planning Committee, described earlier. Long before the MSPT was formed, considerable thought and study had been devoted to developing a broad vision for what might be built. Much of this vision was reflected in the previously described 1998 development agreement with the City of Santa Monica. This agreement, which will be effective until 2008, provides in some detail for the various Phase I projects on the north campus. The development agreement also provided, though in a far less detail, for Phase II. As previously indicated, Phase II presents a complex and difficult planning challenge because of the nature of the property; SJHC owns some, but by no means all, of the parcels in the relevant three-square-block area and might or might not be able to acquire the additional parcels in which it has an interest. Adding to the complexity is the number of separate but related objectives, the uncertainty as to the availability of financing, the staging problems, financing issues, serious traffic problems, the need to comply with the stringent rules of the City of Santa Monica and to satisfy the interests represented by the City, and the need for approval from Leavenworth. And as if that were not enough, the planners needed to project needs and trends in the distant future in a field in which there is rapid and dramatic change-which, among other things, argues for maximum feasible flexibility.

The job of the MSPT was to figure out what should be built, where each element should go, what the entire campus should look like, when each element should be built, and how various problems should be solved. The planning task was to be completed in four months beginning in mid-August 2002. As already suggested, the SJHC objectives were based on a general notion that in order to remain competitive and serve the future needs of the community-in order to fulfill its mission-it needed to create an effective and attractive hospital environment, not limited strictly to hospital needs. A guiding principle was that it would be necessary to generate revenues from some profitable activities in order to support other activities. Another guiding thought was that SJHC was located in an area with an aging population that will "age in place" rather than moving off to retirement communities. This led in turn to the idea that the objective should be not just to heal the sick but to promote wellness and fitness and "healthy aging." More specifically, the following building and other projects had been identified:

\section{A. Parking}

It was plain at the outset that there was a need for parking and, as the planning proceeded, it became clear that the first priority would have to be a 3,500-car parking structure (four levels below grade and three levels above), partly to meet the needs of projected uses on the south campus and partly to meet a parking deficit on the north campus. 


\section{B. A Medical Office Building}

There are a number of medical office buildings presently located in the immediate area, more or less contiguous to the hospital, but more space was needed. A medical office building would be a revenue generator in two ways. First, there would be the rental payments. ${ }^{48}$ Second, the office space would accommodate doctors, who would bring to the hospital patients for its beds, for its operating rooms, and for its ambulatory, diagnostic, and other services. "Build it and they will come" was not considered a viable strategy for the core hospital structure. ${ }^{49}$

\section{A New Building for the John Wayne Cancer Institute}

However, it was recognized during the planning process that research/laboratory facilities could be separated from the patient-care facilities. Only the latter needed to be centrally located.

\section{Health and Wellness Center and Conference Center}

These were somewhat more questionable, but they are important parts of the big vision.

\section{E. Housing}

At the periphery of the south campus there was room for buildings for apartments, townhouses, and assisted-living units.

\section{F. Landscaping}

An essential element of the plan was the development of an attractive and inviting environment, with landscaping and other features designed to enhance the public perception of SJHC, facilitate pedestrian and vehicular traffic, and integrate the north and south campuses.

\section{G. Traffic}

In order to make the hospital attractive to patients, and to satisfy concerns of the City of Santa Monica and its residents, it would be necessary to solve some serious traffic problems.

48. SJHC already owned land on which a medical office building could be built. SJHC could build the building itself (if it could find the money) or it could lease the land to a developer who would commit to building an acceptable medical office building. The latter course would generate revenue that could be used to finance other projects or to support money-losing operations.

49. There were, to be sure, some people who, at least initially, favored limiting development to the core functions. 


\section{FINDING AND HIRING THE TEAMS}

The first step in the planning process was to select two teams, one for design (the Master Site Planning Team) and one to study feasibility (market demand). A key move initially was to hire an experienced person to work with Klein in selecting the team members, communicating the SJHC objectives, and coordinating and directing the planning work. The selection of this person involved reliance largely on an informal network and on reputation conveyed by word of mouth. Klein and Doms were the right kind of people to proceed in this way. They are both experienced and smart. According to Doms, Klein "knows everyone" in the community, particularly in real estate, ${ }^{50}$ and is "very good at building consensus." ${ }^{51}$ Much the same could be said for Doms. ${ }^{52}$

The person selected was Michael P. Russell, who had an impressive record in real estate development and had recently completed a sixteen-month job overseeing planning for a 260 -acre mixed-use redevelopment project for a Boeing aircraft manufacturing facility in Long Beach, California. Russell was plainly well qualified, and he was available. More to the point, he and Klein knew each other ${ }^{53}$ and had previously had informal conversations about the SJHC project. ${ }^{54}$ Doms also knew Russell and had a favorable impression of his professional reputation. Beyond that, Klein and Doms were both part of an informal business and social network heavily populated with successful real estate developers, contractors, and investors (some of them on the board of SJHC or its Foundation), who were able to corroborate Klein's and Doms's impressions.

With all this in mind, it is not difficult to understand why Russell was hired on the basis of his record, his reputation, and interviews but without a formal search or competition. Russell was hired as a nonemployee consultant for a period of nine months at a fixed monthly fee, with the title "Senior Development Advisor."

50. Klein was born and raised and still lives in Pacific Palisades, which is a part of Los Angeles contiguous to Santa Monica. He was a star football player (tight end) at the University of Southern California and later with the Los Angeles Rams and the San Diego Chargers. He is personable and outgoing, and is highly respected. While still playing professional football he pursued a career in commercial real estate. He began working for SJHC in 1992 and before that had been a member of the SJHC Foundation Board of Trustees and an active volunteer fundraiser (as well as a frequent surgical patient during his long career as a football player). He is a lifelong member of the Corpus Christi Catholic church in Pacific Palisades, which is an important link in his connections to knowledgeable people in the community served by SJHC.

51. This observation by Mike Russell (see infra note 52) is confirmed by co-author W. Klein's own observations.

52. Before retiring (to a virtually full-time volunteer role at SJHC), Doms had been a member of a firm that invested in real estate on behalf of large pension funds. While he was not directly involved in real estate development, he came in contact with many who were.

53. They were students at the University of Southern California at the same time; both had lived in Pacific Palisades; and their children went to the same schools.

54. One of those conversations occurred when Russell's son was undergoing surgery at SJHC and Klein and Russell happened to encounter one another there. 
Once Russell came on board, he played a leading role, along with Klein and Doms, in selecting the other members of the teams. Most of the other consultants were, like Russell, selected on the basis of reputation (in many cases being people with whom Russell had worked on projects in the past). One notable exception was the group of four architects who were the central figures on the Master Site Planning team, who were selected as the result of proposals made by groups from five different firms.

\section{The Master Site Planning Team: Membership and Selection}

The people most actively involved in the four-month planning gathered at the hospital in Santa Monica for a three-hour meeting once each week (with some exceptions) and communicated with one another regularly. Except for the client representatives, all of the team members were hired as consultants for a fixed fee (plus expenses, with a maximum amount). The organization of the team is shown in Figure 1, on the following page.

\section{A. The Client Representatives}

The MSPT included the three SJHC representatives previously describedKlein, Doms, and Russell-plus, somewhat less actively, Michael Monaldo, an architect by training and SJHC's director of the Phase I construction. These client representatives played an active role in the planning process.

\section{B. The General Architects}

There were four architects who were responsible for design of the plan and for coordination of the work of the other members of the team: Three of them-Paul Danna, Jose Palacios, and Dana Taylor-had worked together for many years, first at a major architectural firm (Skidmore, Owings \& Merrill), then in their own firm, and for the past eight years at DMJMH $+\mathrm{N},{ }^{55}$ a large firm itself ${ }^{56}$ and a subsidiary of an even larger firm, AECOM. ${ }^{57}$ Their work spaces were contiguous to one another and they tended to operate as a team within the architecture division of DMJMH+N. The fourth DMJMH+N architect, Alton Chow, was a junior participant for the SJHC project. ${ }^{58}$

The $\mathrm{DMJMH}+\mathrm{N}$ team was selected after a competition in which proposals were presented by five different teams. The $D M J M H+N$ team devoted considerable time and expense to preparing and presenting its proposal-an investment for which there would have been no return if another team had been

55. See DMJM Website, at http://www.dmjmhn.com (last visited Sept. 11, 2002).

56. It had about sixty architects plus engineers, landscape architects, and interior designers. Id.

57. See AECOM Website, at http:/www.aecom.com (last visited Mar. 1, 2004).

58. He had, however, worked for $\mathrm{DMJMH}+\mathrm{N}$ for five years. 


\section{Economic Organization in the Construction Industry}

selected. ${ }^{59}$ It was the team of Danna, Palacios, and Taylor (later joined by Chow) that won the contract, not the firm of DMJMH+N ${ }^{60}$ an observation that is explored more fully below.

59. A more extreme form of this sort of investment of time with no assurance of compensation is found with investment bankers, who provide advice without charge in the hope of a large fee when a transaction is accomplished. See ROBERT G. ECCLES \& DWIGHT B. CRANE, DONG DEALS: INVESTMENT BANKS AT WORK 39 (1988).

60. The contract was between SJHC and DMJMH+N, with Klein signing for SJHC and Taylor signing for $\mathrm{DMJMH}+\mathrm{N}$. The contract amount kept the project within limits that allowed Taylor to sign for $\mathrm{DMJMH}+\mathrm{N}$ without approval from anyone else in the firm. 


\section{The Landscape Architects}

As part of their proposal to SJHC, the DMJMH+N team-Dana, Palacios, and Taylor-represented that it had an agreement with Bob Hale and Mark Tessier of Rios Associates to provide landscape services. In other words, Rios was to be a subcontractor of DMJMH+N. Hale and Tessier took part in the presentation to SJHC that resulted in the award of the contract to DMJMH+N. They had recently worked successfully on the design of various parks in the City of Santa Monica. Because the SJHC people were concerned about the commonly perceived difficulty in satisfying the City and complying with its rules, ${ }^{61}$ this was a significant benefit. In addition, Rios Associates had recently served as landscape architect for a master plan for a major hospital in the West Los Angeles area (Cedars-Sinai Medical Center). Moreover, Hale had an excellent reputation ${ }^{62}$ and was known to and had worked on projects with Russell.

DMJMH+N had its own landscape architects, who could have provided the landscape-design services. The choice by Danna, Palacios, and Taylor of the Rios architects created some tension within DMJMH+N, but Danna, Palacios, and Taylor believed that SJHC probably would not award the contract to them without Rios-a surmise later confirmed by Klein.

\section{Residential Architect}

$\mathrm{DMJMH}+\mathrm{N}$ also subcontracted for residential architecture, with Ron Nestor of the firm of Nestor and Gaffney. Again, the services could have been provided by architects within $\mathrm{DMJMH}+\mathrm{N}$, but it was thought that bringing in Nestor was important in winning the contract.

\section{E. Civil Engineer}

SJHC hired the civil engineer, ${ }^{63}$ Nicole Kerry of Kimley-Horn and Associates, Inc. ${ }^{64}$ Kerry had worked previously with Russell and he held her in very high regard. Klein explained that he and Russell wanted to pick the civil

61. The City has rules covering, among other things, what trees could be removed and what types of new trees could be planted. Part of what Hale and Tessier brought to the project was their knowledge of these rules.

62. At the time of this project, Hale was president of the Los Angeles branch of the American Institute of Architects. See ALA Los Angeles Website, at http://www.aialosangeles.org (last visited Nov. 19, 2001) (listing Hale as President at that time).

63. The civil engineer is responsible for locating utilities, helping in planning to accommodate to their existence, planning for the delivery of utilities to new structures, planning for drainage, etc. Generally, the civil engineer is responsible for planning the delivery of utilities to within five feet of the envelope of a building, where the building engineers take over. The architects need to know, for example, where underground utilities are located before they can decide where to place underground structures such as subterranean parking. Utilities can be relocated, but that can be costly.

64. See Kimley-Horn \& Associates, Inc. Website, at http://www.kimley-hom.com/kha/ (last visited Mar. 1, 2004). 
engineer, rather than leaving that choice to the $\mathrm{DMJMH}+\mathrm{N}$ team, because the job had a vital bearing on the entire hospital operation.

\section{F. Traffic and Parking Specialists}

Because of substantial increases in office development in the area near SJHC, traffic problems had arisen and traffic and parking had become a serious concern for the City. To deal with the traffic and parking, SJHC hired Sam Ross, president of Crain \& Associates, a firm of about thirty professionals specializing in traffic engineering and transportation planning. Another member of the firm, Diana Skidmore (the only member of the firm who is an architect), also attended some MSPT meetings, generally when Ross was not in attendance. As with the civil engineer, Russell and Klein considered it important for them, rather than the design architect, to select the traffic engineer. Ross was hired without competitive bidding. Klein and Russell feared that if they had had a competition there was a risk that they were unwilling to take that they might not get the qualities they wanted. Russell had worked before with Ross and had confidence in him.

\section{G. Construction Specialist}

Near the end of the planning process, SJHC brought in John R. Gavan, managing principal of KPFF (consulting engineers). ${ }^{65}$ Gavan's role was to advise on construction requirements that might affect design. For example, when the design reached a point of focusing on a parking garage with three or four levels below ground and three above, with the possibility of a building on top of that, he advised on the necessary size of the columns needed in the lower levels of the parking garage, to support the upper levels. The size of the columns would obviously affect the design of the garage and the number of parking spaces, which was important to Ross, the traffic and parking consultant, as well as to the design architects.

\section{H. Silent but Powerful Members: The City of Santa Monica and Its Citizens}

While the City of Santa Monica was not involved in the phase of the project that is the direct focus of this study, throughout the planning process all members of the planning team were consciously aware of and expressly and openly deferential to the formal and informal requirements and potential objections of the City and of individuals (e.g., neighbors) and nongovernmental organizations. It was always an implicit, and often an explicit, assumption that the City (both the agencies and the more politically oriented City Council) retained substantial discretion over approval or disapproval of various aspects

65. See KPFF Website, at http://www.kpff.com (last visited Mar. 1, 2004). 
of the project.

\section{THE FEASIBILITY TEAM}

SJHC also hired a number of "feasibility" consultants-people who estimated demand. These included people from: ${ }^{66}$ (strategic planning and market assessment for ambulatory care and for the medical office building); The Camden Group $^{67}$ (demand analysis in general and for research zone); Cornerstone Decision Support (demand analysis for fitness and wellness center); Economic Research Associates (feasibility of educational conference center); RCL \& Co. (feasibility of employee and market rate housing); Gerontological Services, Inc. (feasibility of assisted living housing and lifestyle center); Robert Charles Lesser \& Co. (residential feasibility); and Webcor (construction analysis).

Klein, Russell, and Doms met with these feasibility consultants and then communicated the results to the MSPT. There was some collaboration among the feasibility consultants, but their efforts were not observed as part of this study.

\section{OBSERVATIONS, THEORIES, INFERENCES, AND QUESTIONS}

\section{A. The Culture of Collaboration}

The work of the professionals involved in the SJHC Phase II master site planning project is a small-scale example of an important aspect of construction projects-namely, the culture of collaboration. ${ }^{68}$ Collaboration means not just an ability to work together-not just doing one's part in a joint project-but adaptability and responsiveness to the needs of other members of the team. As such, it illustrates an aspect not only of the construction industry, and other

66. See Hammes Company Website, at http://www.hammesco.com/au/index.php (last visited Mar. 1, 2004).

67. See The Canden Group Website, at www.TheCamdenGroup.com/about.asp?page=about (last visited Nov. 17, 2003).

68. For a reference to the source of this phrase, see supra note 7 (referring to the 3D/I website). A more extreme, and to some degree unique, example of collaboration arose in the reconstruction of the portion of the Pentagon destroyed on September 11, 2001. The key people responsible for that job adopted the seemingly impossible goal of reopening within one year-and succeeded. "Rebuilding the Pentagon took teamwork, creativity, and some ingenuity. The workers also shared a tremendous amount of patriotism, personal pride and emotion-not to mention 20-hour days, six or seven days a week." Sherie Winston, Pentagon's Construction Team Beats the Odds on One-Year Rebuild: Motivation and teamwork shave three years from schedule, 249 ENGINEERING NEWS-RECORD 6 (Sept. 2, 2002). The government's representative "made it clear that 'we operate as a partnership." Id. The contractor's lead on-site executive noted that no one had a written contract and that "Everyone left their egos in the [Pentagon's] south parking lot." $J d$. For a soul-stirring, and more detailed, story of the rebuilding, see Steve Vogel, From Ruins, Pentagon Rises Renewed; Determined Crews Keep Their Promise to Return Workers, WASH. POST, Sept. 8, 2002, at Al. 
project-based industries such as motion picture production, ${ }^{69}$ but also of other economic activities characterized by cooperation in a nonhierarchical setting. ${ }^{70}$ More broadly, by inference, it is at least suggestive as to other nonhierarchical economic relationships, particularly those that are multilateral. Collaboration in turn involves trust and reputation. ${ }^{71}$ It is of some relevance that the pool of professionals from whom the MSPT members were selected was of the type that reliable reputational information was available to the SJHC executives and their advisors without excessive effort. This final point is one to which we will return. $^{72}$

Thus, in the case of the SJHC project, a prime criterion for initial selection was reputation for being a "team player." 73 Once the team began work, it was plain to the observer's eye ${ }^{74}$ that the members of the team expected to and did rely on and cooperate with one another. They had frequent meetings, telephone

69. See Laubacher et al., supra note 6, at 8 ("On large projects in the film industry today, hundreds or even thousands of individuals and small entities contribute their part to the completion of a multimillion dollar production."). The article refers to other firms that rely heavily on outsourcing, including Nike (athletic shoes) and the personal computer display division of Nokia, which "accounted for sales of over $\$ 150$ million in 1995 and has only five employees." $l d$. at 9.

70. For authorities cited, see DuBOIS, supra note 10.

71. The trust observed in this study seems to be mostly of the type that has been called "knowledge-based trust," derived from adequate information, and "identification-based trust," based on "empathy with the other party's desires and intentions," and not much of the "deterrence-based" type, based on punishment. See Roy J. Lewicki \& Barbara Benedict Bunker, Developing and Maintaining Trust in Work Relationships, in TRUST IN ORGANIZATIONS, supra note 6, at 118-19.

The commitment to collaboration can be (though it need not be) described as a custom or norm, which is likely to some extent to be internalized and which serves the goals of faimess and efficiency. See Symposium, Norms and Corporate Law, 149 U. PA. L. REV. 1607 (2001); David Chamy, Non-legal Sanctions in Commercial Relationships, 104 HARV. L. REV. 373 (1990); Robert D. Cooter, Decentralized Law for a Complex Economy: The Structural Approach to Adjudicating the New Law Merchant, 144 U. PA. L. REV. 1643 (1996); Edward B. Rock \& Michael L. Wachter, Islands of Conscious Power: Law, Norms, and the Self-Governing Corporation, 149 U. PA. L. REV. 1619 (2001) (claiming persuasively that "corporate law can be understood as a remarkably sophisticated mechanism for facilitating govemance by NLERs" (non-legally enforceable rules and standards)). There is a large body of recent literature on norms, customs, and trust and on law and behavioral science. See, e.g., Christine Jolls et al., A Behavioral Approach to Law and Economics, 50 STAN. L. REV. 1471 (1998); Russell B. Korobkin \& Thomas S. Ulen, Law and Behavioral Science: Removing the Rationality Assumption from Law and Economics, 88 CORNELL L. REV. 1051 (2000); Donald C. Langevoort, Behavioral Theories of Judgment and Decision Making in Legal Scholarship: A Literature Review, 51 VAND. L. REV. 1499 (1998); Larry E. Ribstein, Law v. Trust, 81 B.U. L. REV. 553 (2001) (containing a brief summary); Stephen M. Bainbridge, Corporate Decisionmaking and the Moral Rights of Employees: Participatory Management and Natural Law, 43 VILLANOVA L. REV. 741 (1998); Margaret M. Blair \& Lynn A. Stout, Trust, Trustworthiness, and the Behavioral Foundations of Corporate Law, 149 U. PA. L. REV. 1735 (2001). Most of the literature does not bear directly on the present study and, at least for present purposes, some of it seems to overanalyze phenomena such as collaboration, trust, and reputation-too much theorizing chasing too few facts. In the category of overanalysis, a leading example is Francis fukuYama, Trust: The Social Virtues and the Culture of Prosperity (1995).

72. See infra notes $90-95$ and accompanying text.

73. Mike Russell analogized the project to a basketball team on defense, where, in a fast-changing situation, each player should know what the other is going to do and should be able to rely on being backed up as needed.

74. Co-author William Klein sat in on all but one of the weekly MSP'T meetings and interviewed most of the participants, asking them in particular about teamwork and collaboration. 
conversations, and exchanges of documents, drawings, and plans (largely by electronic means), and operated in a collegial, mutually respectful manner.

An important generalization, then, seems to be that coordination does not require a firm or the power of fiat--and may even be more effective without firm or fiat.

\section{B. Firms and Markets}

In the traditional and still-dominant economic models of economic organization, transactions are divided between those within firms and those across markets. ${ }^{75}$ Oversimplifying, firms are deemed to house the "black box" of production and the goods that they produce are then traded among firms and individuals on markets. In law, the analogous dichotomy is between contract law, on the one hand, and the law of agency and of business organization on the other hand. ${ }^{76}$ The present study shows that for some significant set of economic activity, that dichotomy simply does not work. ${ }^{77}$ Because the dichotomy does

75. See OLIVER E. WILlIAMSON, MARKETS AND HIERARCHIES: ANALYSIS AND ANTITRUST IMPLICATIONS (1975). But see OLIVER E. WILLIAMSON, THE ECONOMIC INSTITUTIONS OF CAPITALISM 6-7 (1985) (offering discussion that is devoted mainly to the firm-versus-market distinction but that offers the observation (with an attribution to Ronald Coase) that "the study of internal organization and market organization are not disjunct but rather are usefully joined within a common transaction cost economizing framework"). Even if economizing on transaction costs is the unifying theme, however, the focus on those costs stems from the initial inquiry into why transactions are sometimes organized within firms and sometimes across markets, with an assumption of the explanatory virtue of the firm-versusmarket dichotomy. Moreover, the transaction-cost explanation of the boundaries of the firm has now been joined by other explanations. See Holmstrom \& Roberts, supra note 10, at 74-75; Steven Tadelis, Complexity, Flexibility, and the Make-or-Buy Decision, 92 AM. ECON. REV. PAPERS \& PROCEEDINGS 433 (2002); see also Harold Demsetz, The Theory of the Firm Revisited, in THE NATURE OF THE FIRM: ORIGINS, EVOLUTION AND DEVELOPMENT 159, 167 (Oliver E. Williamson \& Sidney G. Winter, eds., 1991) (objecting to the focus on transaction-cost and monitoring explanations for the existence of firms and disregarding or downplaying the role of "moral hazard analysis, shirking, and opportunism-the problems of incentive compatibility").

Oliver Hart and John Moore offer this theory:

We argue that the crucial difference for party 1 between owning a firm (integration) and contracting for a service from another party 2 who owns this firm (non-integration) is that, under integration, party 1 can selectively fire the workers of the firm (including party 2), whereas under non-integration he can "fire" (i.e., stop dealing with) only the entire firm: the combination of party 2 , the workers, and the firm's assets.

Oliver Hart \& John Moore, Property Rights and the Nature of the Firm, 98 J. POL. ECON. 1119 (1990). This statement seems to tell us little, if anything, of interest about SJHC and the team it engaged for its master site planning project.

76. The present study may reflect the fact that its authors specialize in the law of business organization (including agency) rather than in the law of contracts, and may have paid too little attention to the literature on relational contracts. See Robert E. Scott, $A$ Theory of Self-Enforcing Indefinite Agreements, 103 CoLUM. L. REV. 1641, $1644-45$ (2003) (presenting a theory that "predicts that selfenforcement of deliberately incomplete agreements between strangers is more efficient than the altemative of more complete, legally enforceable contracts").

77. Cf. Dent, Jr., supra note 10, at 71 ("In theory, business is transacted either in markets or in firms; a firm chooses to "make-or-buy' each input it needs. Strategic alliances fit neither category.") (citations omitted). For more on strategic alliances, see Robert M. Grant \& Charles Baden-Fuller, Knowledge and Economic Organization: An Application to the Analysis of Interfirm Collaboration, in KNOWLEDGE CREATION: A SOURCE OF VALUE, supra note 10, at 113-50. It is relevant that Scott takes as given that where, in repeat dealings, reputation is at stake, contracts tend to be self-enforcing. The 
not work, extrapolating from it to account for "hybrids" economic phenomenon that stands on its own. ${ }^{79}$ The collaborative team described in the present study has a number of defining characteristics.

First, the professionals within the team were from different firms. Production took place outside their firms (or, at best, at the periphery of the firms). There were firms in the picture and they were in some sense involvedthey "supplied" the team members. But the transactions among the firms, and among the members of the team, were not transactions across markets as such transactions are usually conceived. ${ }^{80}$

Second, within the production team, there was no hierarchy and no power of fiat of the sort one expects in a traditional firm. ${ }^{81}$ The members of the $\mathrm{DMJMH}+\mathrm{N}$ team provided leadership and coordination, but they did not issue orders. They did not exercise the control over others that plays such an

cited paper extends the theory to one-shot deals.

78. See Oliver E. Williamson, Comparative Economic Organization: The Analysis of Discrete Structural Alternatives, 36 ADMIN. SCI. Q. 269, 280 (1991) ("Markets and hicrarchies are polar modes.... [H]owever, a major purpose of this paper is to locate hybrid modes-various forms of longterm contracting, reciprocal trading, regulation, franchising, and the like-in relation to these modes.").

79. See Walter W. Powell, Neither Market Nor Hierarchy: Network Forms of Organization, 12 RES. ORG. BEHAV. 295, 299 (1990):

The idea that economic exchanges can be usefully arrayed along a continuum is thus too quiescent and mechanical. The continuum view also misconstrues patterns of economic development and blinds us to the role played by reciprocity and collaboration as alternative governance mechanisms. By sticking to the twin pillars of markets and hierarchies, our attention is deflected from a diversity of organizational designs that are neither fish nor fowl, nor some mongrel hybrid, but a distinctly different form.

Powell goes on to state that a "hierarchical structure ... is particularly well-suited for mass production and distribution," while "[n]etworks are particularly apt for circumstances in which there is a need for efficient, reliable information." Id. at 303-04. What Powell seems to have mostly in mind, however, are semi-permanent network alliances ("durable relationships," $i d$. at 306), or so-called strategic alliances, though he does refer, among his examples, to construction (id. at 306) and the "film and recording industries" (id. at 308).

For an historical study making a similar point (though focusing on manufacture rather than services), see Naomi R. Lamoreaux, Daniel M.G. Raff \& Peter Temin, Beyond Markets and Hierarchies: Toward a New Synthesis of American Business History (2002) (NBER Working Paper No. W9029), available at http://papers.ssm.com/sol3/papers.cfm?abstract_id=317614.

80. Each of the firms did have a contractual (market) relationship with SJHC, but those contractua relationships were used to create a production team, not to exchange goods or services directly.

81. In modem firms, the traditional theoretical distinction between firms and markets is increasingly undercut by the substitution of team production for hierarchy. See Watts, supra note 10 Watts explains:

[W] hen a firm embarks on a major new project, the people involved don 't actually know how

they are going to do it. In fast-moving industries from software to automobiles, designs are rarely final before production itself has commenced, and performance benchmarks evolve along with the project. Furthermore, no one person's role in the overall scheme is ever precisely specified in advance. Rather, each person starts with a general notion of what is required of him or her, and refines that notion only by interacting with other problem solvers (who, of course, are doing the same).

Id. at 268 (italics in original). Watts goes on to state, "The result, in a successful firm, is a continual swirl of problem-solving activity.... Id. at 269. Earlier in the book, Watts had offered the important related observation that often, in problem-solving networks (not necessarily in firms), there is not only an absence of hierarchical control but there is no "center" or there are many centers, and "innovations originate not in the core of the network but in its peripheries." $I d$. at 52. 
important role in legal doctrine and theory and in the traditional economic theory of the firm. Thus, the present study suggests that perhaps the distinction between control over employees and control over independent contractors, and the corresponding distinction between firms and markets, is less clear-cut, and less significant, than legal doctrine and legal and economic theory presume. ${ }^{82}$

Third, SJHC did not, except in a narrow legal sense, hire the firms of which the MSPT members were principals or employees. The hiring process may have been influenced to some degree by the reputations and the capital of the firms, but that process focused more on the individuals who would perform the services. For example, the people making the decision at SJHC would not have been willing to hire $\mathrm{DMJMH}+\mathrm{N}$ and allow $\mathrm{DMJMH}+\mathrm{N}$ freedom to select the individuals within the firm who would perform the services. ${ }^{83}$ In fact, while $\mathrm{DMJMH}+\mathrm{N}$ had an excellent general reputation, the SJHC people considered its conservative style to be a negative attribute, a deficiency that the $\mathrm{DMJMH}+\mathrm{N}$ team remedied by taking on Hale, Tessier, and Nestor as subcontractors. On the other hand, it may be that the backing of a major firm did add a comfort factor for SJHC that supported the Danna-Palacios-Taylor

82. This point was made long ago by Alchian and Demsetz. Armen A. Alchian \& Harold Demsetz, Production, Information Costs, and Economic Organization, 62 AM. ECON. REV. 777 (1972). In the literature on firms and markets, however, it is sometimes noted and then generally ignored. In legal theory, a plumbing contractor can tell its employees how to do their job; it has the power of fiat. A general contractor, by contrast, lacks this legal power over the plumbing contractor. So what? If the general contractor, for some good reason, directs the plumbing contractor to do something unanticipated or unusual, the plumbing contractor is unlikely to object (though some financial adjustment may be required). Likewise, if the plumbing contractor directs its employee to do something reasonable, though perhaps unusual and unanticipated, the employee is unlikely to object. For a somewhat different and more generalized version of the argument, see Mark Granovetter, Economic Action and Social Structure: The Problem of Embeddedness, 91 AM. J. SOC. 481, 499-502 (1985) (citing empirical studies calling into question the idea that hierarchically organized firms have effective power of fiat).

The idea originated by Alchian and Demsetz is echoed in WILLIAM A. KLEIN \& JOHN C. COFFEE, JR., BUSINESS ORGANIZATION AND FINANCE 14-19 (8th ed. 2002), which focuses on control. In both law and economics, control is the critical element in distinguishing between employment (firm) and contract. See id. at 19-21, suggesting that that there is a continuum between firms and markets, with varying degrees of "firmishness," depending on a variety of bargain elements. See also G. Mitu Gulati et al, Connected Contracts, 47 UCLA L. REV. 887 (2000) (reiterating the point about degrees of firmishness).

83. The same focus on the individual rather than the firm was even clearer with respect to the other members of the MSP team, who were hired without any formal competition. For example, Mike Russell spoke about why he and Bob Klein hired Nicole Kerry, the civil engineer, without saying anything about the firm of which she was a member. It may be, of course, that her affiliation with a firm of good reputation was an implicit condition of her selection. It may also be true that she could not have been fully effective without the support of others within the firm. Yet the fact remains that the relationship between Kerry and her firm (Kimley-Horn), and the relationship between her, her firm and SJHC does not fit easily in the traditional model of firms and markets.

At a meeting of the Master Site Planning Committee in January 2003, attended by, among other committee members, three successful real estate developers, the prospect was raised of hiring legal services for acquiring the legal entitlement to take Phase II to the next stage. When ideas were informally solicited about whom to hire, there were eight or ten quick suggestions - all of them names of individual lawyers. In some, but not all, cases the names of the firms were appended to the names of individuals, but no one offered the name of a firm alone. A draft memorandum for seeking proposals from law firms for various legal work included the statement, "We want to know the partners and any associates who will be working with us on this assignment." 
proposal. This raises the question, when a client hires a professional who is a member of a firm, what does the client expect of its relationship with the individual professional and of its relationship with the firm? The same question can be posed for law firms, and the answer may vary with the client, the type of matter, and the size, traditions, and organizational structure of the firm. The point is, once more, that the concept of a "firm" is a simplification. ${ }^{84}$ A central feature of the notion of a firm in economics and of an employer in agency law is control by the firm or employer over its employees. The present study suggests that in some (many?) situations the notion of control that defines firms and employment fails to mesh with (indeed, falsifies) reality-as does the notion of markets, bargains, and contracts. ${ }^{85}$

Fourth, the individual MSPT members had considerable autonomy within their firms. They were much more like partners in a law firm than like executives in a major manufacturing corporation. While for many purposes it may be useful to refer to both law firms and manufacturing corporations as "firms," it is also clear that that lumping-together obscures important aspects of reality. To put that idea in other terms, Paul Danna is an "employee" of $\mathrm{DMJMH}+\mathrm{N}$ and Bob Klein is an "employee" of SJHC, but their connections to their employers are significantly dissimilar. Danna's human capital-his skill, reputation, etc.-is readily transferable to other firms; his human capital is not "firm specific." Klein's skills at management are more generic perhaps-there are more types of jobs for which he would be qualified - but at the same time much of his value is tied to SJHC. The legal concept of an employee-a "servant-type agent" distinction, as does the distinction in economic theory between firms and markets. To put this idea in still other terms, it may be that we should think not of a firm like DMJMH $+\mathrm{N}$ hiring architects, or of a large law firm taking in partners and hiring associates, but rather of the individual architects or lawyers

84. Compare Equal Employment Opportunity Commission v. Sidley Austin Brown \& Wood, 315 F.3d 696 (7th Cir. 2002) (addressing the question whether certain "partners" of a law firm were "employees" for purposes of the federal prohibition on age discrimination). Sidley Austin Brown \& Wood was controlled by a self-perpetuating executive committee, which delegated authority to other committees, which remained subject to its ultimate control. In a concurring opinion, Judge Easterbrook speculated:

Perhaps each practice group at a large law firm is best viewed as a distinct venture, and the umbrella organization (run by the Executive and Management Committees at Sidley) as a partnership of partnerships. The top committees can make all decisions, but much power is bound to be delegated, just as departments at a university make their own hiring and salary decisions even though a self-perpetuating board of trustees holds all the legal authority. Id. at 710 .

Even within each "practice group," one can easily imagine that there were individual partners with substantial autonomy derived from, among other things, their productivity and their relationships with clients, other members of the firm, and associates.

85. In many types of construction projects, moreover, the contractors do not select their employees. A contractor may have a small permanent staff of crew chiefs, while the rest of the workers for any particular project are assigned by a union from its hiring hall.

86. See RESTATEMENT (SECOND) OF AGENCY $§ 2$ (1958). 
engaging certain specified management, accounting, monitoring, and marketing services, ${ }^{87}$ and taking advantage of networks of relationships.

Finally, as previously noted, Danna, Palacios, and Taylor chose landscape architects and a residential architect from outside of $\mathrm{DMJMH}+\mathrm{N}$, despite the fact that this created some tension within the firm.

All this raises the question, why did the architects join a large firm? In fact, Danna, Palacios, and Taylor had, early in their careers, worked at Skidmore, Owings \& Merrill, LLP. In 1990 they left that firm and went out on their own. Four years later, their small firm had grown to one with about sixty architects, and then was acquired by DMJMH+N. Paul Danna offered two main reasons for his support of this latter move. One reason was that the firm provided its members with security, tiding them over in the lean times. His second reason was that working with a large firm gave him the opportunity to work on largerscale projects than would otherwise have been available to him, an opportunity that appealed to him for largely nonpecuniary reasons. It is conceivable that he could have worked as an independent contractor on larger projects or that he could have (with Dana Taylor and Jose Palacios) put together ad hoc teams for such projects. But that seems impractical. Presumably, the firm could more efficiently provide marketing capabilities and an array of services to clients reluctant to seek out specialists (or to allow their prime lawyer to do so), ${ }^{88}$ financial weight; monitoring of the performance of its architects; access to networks; and reputational capital. ${ }^{89}$ And bear in mind, Danna, Palacios, and Taylor retained considerable autonomy.

87. Similarly, one could, with some stretch, think of the Japanese automobile parts suppliers hiring, say, Toyota for coordination, design, marketing and other services, rather than Toyota hiring the suppliers. See supra note 10 . The point is not that either perspective is right but rather that neither is wrong and each may be useful-or that both are myopic and what we need is a fresh perspective.

88. See Randall S. Thomas et al., Megafirms, 80 N.C. L. REV. 115 (2001) (explaining the rise of large firms in response to, among other factors, the desire of clients for "one-stop shopping" for large, complex matters).

89. Clients of law firms are, like clients of architectural firms, likely to select the individual members of the firm with whom they intend to do business. It may be, as suggested above, that law firms are most fundamentally a combination of (a) guilds, (b) marketing cooperatives, (c) mutual insurance societies, and (d) screening, certification, and monitoring agencies. If you strip away those functions, what is left? (It is easy enough to imagine outsourcing the accounting and propertymanagement functions.) For other suggestions as to the role of firms more generally, see Richard A. Booth, Form and Function in Business Organization (2003) (unpublished paper), available at www.ssm.com/abstract $=378740$. The firm is still a valuable and important reality. The point is that the productive work for clients is done not so much within the firm, as in the manufacture of pins, but rather independently of the firn. Cf. Stephen C. Yeazell, Re-Financing Civil Litigation, 51 DEPAUL L. REV. 183 , 199-200 (2001). Yeazell points out that lawyers in firms, compared with solo practitioners, can more casily specialize and acquire expertise, which yields retums to scale and marketing advantages. Moreover, he adds, the firm, with its indefinite duration, enhances the feasibility of amassing firmspecific capital, including both physical assets such as a library and intangible assets such as reputation. A firm also allows lawyers to "hedge their bets" by taking on a variety of high-risk and low-risk work. However, Yeazell later points out that "[ $t$ ]he plaintiffs" [personal injury] bar has used inter-firm referral and fee splitting to achieve a network of expertise that replicates many of the advantages of larger firms." Id. at 203. 


\section{Economic Organization in the Construction Industry}

\section{Networks and Relationships}

The hiring of the various consultants who formed the planning team was largely the product of an informal network ${ }^{90}$ of relationships that supplied information about reputation for quality of work and for being a team player. ${ }^{91}$ The set of professionals from which the MSPT members were selected, and the set of real estate investors and developers with knowledge of their reputations, was small enough and socially homogeneous enough to make this method of selection feasible and effective. ${ }^{92}$ That said, this network of individuals in the Los Angeles construction industry was a far cry from the small, closed, often ethnically homogenous, communities (communities whose members have "strong ties" to one another), where reputational and social sanctions serve as a substitute for law. ${ }^{93}$ Here, the community was relatively large and ethnically diverse and the ties, while present, were much weaker than those in the classic studies of either the ranchers in Shasta County or the orthodox Jewish diamond merchants in New York. ${ }^{94}$ The relatively weaker ties were seemingly unavoidable, given the scope of the project and the corresponding need to assemble a broad and diverse group of specialists. The nature of the network, however, was such that these relatively loose and weak ties seemed nevertheless to cohere into an effective mechanism for non-legal sanctioning. ${ }^{95}$

90. We use the word "network" here to refer not to a formal set of business relationships, but rather to the informal set of social and business connections that people in various business activities rely upon, to varying degrees, to share information, particularly about the skill and trustworthiness of potential business associates, employees, and professionals.

91. See supra Part IV. A similar observation could be made for many other economic activities. For example, Frank R. Kline, a partner in a leading venture capital firm, Kline Hawkes \& Co., stated, "The venture business is truly a relationship business." Interview with Frank R. Kline, Partner, Kline Hawkes \& Co, Los Angeles (Jan. 15, 2003). Kline elaborated that almost all of the many deals in which his firm, or the firm in which he had previously worked, invested came from people he knew-lawyers, investment bankers, people involved in other deals in which he had participated, other venture capitalists, etc. Id. For more information about this firm, see Klein Hawkes \& Co Website, at http://www.klinehawkes.com (last visited Mar. 27, 2003).

92. Compare Janet T. Landa, A Theory of the Ethnically Homogeneous Middleman Group: An Institutional Alternative to Contract Law, 10 J. LEGAL STUDIES 349, 361 (1981) (describing certain ethnically homogeneous middleman groups (EHMGs) as alternatives to contract law and to the vertically integrated firm and suggesting that "socially" might be substituted for "ethnically"). See also Stephen M. Bainbridge, Corporate Decisionmaking and the Moral Rights of Employees: Participatory Management and Natural Law, 43 VILLANOVA L. REV. 741, 799-800 (1998).

93. See, e.g., Eric Posner, A Theory of Contract Under Conditions of Radical Judicial Error, 94 Nw. U. L. REV. 749, 755 (stating that the standard view is that non-legal sanctions are effective primarily in "small and homogenous" communities).

94. The references in the text are to the studies of extralegal enforcement mechanisms by Robert Ellickson and Lisa Bemstein. See ROBERT C. EllickSON, ORDER WITHOUT LAW (1991); Lisa Bernstein, Opting Out of the Legal System: Extralegal Contractual Relations in the Diamond Industry, 21 J. LEGAL STUD. 115, 143 (1992); Robert C. Ellickson, Of Coase and Cattle: Dispute Resolution among Neighbors in Shasta County, 38 STAN. L. REV. 623 (1986); Avner Greif, Contract Enforceability and Economic Institutions in Early Trade: The Maghribi Traders Coalition, 83 AM. ECON. REV. 525 (1993); Avner Greif, Reputation and Coalitions in Medieval Trade: Evidence on the Maghribi Traders, 49 J. ECON. HIST. 857-82 (1989); John McMillan \& Christopher Woodruff, Private Order Under Dysfunctional Public Order, 98 MICH. L. REV. 2421 (2000).

95. That there could be strength in weak ties was recognized in Mark Granovetter's classic article, 


\section{Contracts, Specification, and Trust}

The contracts reflect the problem of "bounded rationality" or "incompleteness"- that is, the difficulty of specifying what each consultant was expected to do. ${ }^{96}$ Consider the contract with DMJMH+N. It was drafted by SJHC's lawyer and contained provisions for the fee and the term, plus a number of standard provisions for books and records, warranties, confidentiality, ownership of documents, etc. ${ }^{97}$ The key provision was the "specification of services." This was three and a half pages long and included a detailed schedule of activity and coverage, as well as lists of "deliverables" including the "Overall Development Site Plan," the "Landscape Schematic Plan, Specimen List \& Plant Photographs," the "Pedestrian Circulations Plan," the "Conceptual Site/Building Sections," etc., as well as drawings (renderings) and models. ${ }^{98}$ All of this would, of course, require some minimum amount of effort. But it would not provide the basis for a viable legal claim for failure to deliver a high level of skill and effort. In other words, a range of effort was legally permissible, so there must be some mechanism, other than legal sanctions, to give the client reasonable assurance of best efforts. Our impression was that the primary mechanism here was trust and that reputational

The Strength of Weak Ties, 78 AM. J. SOC. 1360-80 (1978). For a recent discussion of Granovetter's classic work and its relationship to network theory, see WATTS, supra note 10, at 47-50. For other recent work along these lines, see ALBERT-LÁszLó BARABASI, LINKED: THE NEW SCIENCE OF NETwORKS (2002); MARK BUCHANAN, SMALL WORLDS AND THE GROUNDBREAKING SCIENCE OF NETWORKS (2002).

96. For a good brief discussion of bounded rationality and its consequences, see PAUL MILGROM \& JOHN ROBERTS, ECONOMICS, ORGANIZATION \& MANAGEMENT 129-40 (1992). "Because real people are boundedly rational, complete contracts that specify what they will do in every conceivable circumstance are impossible to negotiate and write." $I d$. at 160. And, of course, some contractual rights and obligations are more difficult to specify than others.

For another good example of bounded rationality, consider the contract for the renovation of the Pentagon-a huge long-term project for what amounted to reconstruction of about four million of the five million square feet of office space in the building:

[T] here is no reasonable expectation between the parties that the contract in fact addresses all possible changes that will occur. In fact, the parties understand that in would be impossible to write such a contract.

Public Release Version of the Pentagon Renovation Wedges 2-5 Request for Proposal 3 (2001) (on file with authors). Another part of the same request for proposals puts it this way:

Many of the required services are known only in general terms. Consequently the specific tasks to be performed under this contract may vary from time to time. Hence the Contractor shall provide services under this contract under a cost reimbursable basis.

Id. at $\$ \mathrm{C} \| 1.3$.

97. The contract is relatively brief and skillfully drafted. The same form was used for all the contracts other than Russell's, which he and Klein developed from a form that Russell had previously used. There are myriad form contracts available in the construction industry. For a sample, see Sweet, supra note 4, at A-1 to I-48. See also infra note 109 (describing the basic types of contracts used and their underlying rationales).

98. The "Description of Services" in the contract with the civil engineering firm (Kimley-Hom) provided for a base map with site constraints, a grading plan, a storm drainage plan, a sanitary sewer plan, and a water plan, and required appropriate coordination with the architects or owner or other engineers. It also specified attendance at four-hour weekly meetings for four months. Similar specificity was provided in the contracts with other consultants. 
sanctions were important but at best served to reinforce trust. ${ }^{99}$ This trust-based explanation is relevant because of another, related explanation (other than high uncertainty) for the failure of the parties to attempt to cover more contingencies in the contracts-namely, that an effort by the client to specify, in detail, a minimum level of performance might be interpreted, or misinterpreted, as a signal of a lack of trust or confidence, and that might sour the relationship.

Interestingly, the contract between SJHC and DMJMH+N had not been signed by the time the services that it covered had been completed. The two parties had been unable to reach agreement on warranty and indemnification provisions that were favorable to SJHC and unacceptable to Taylor of $\mathrm{DMJMH}+\mathrm{N}$. These provisions had little if any significance for the task for which $\mathrm{DMJMH}+\mathrm{N}$ was initially hired, but more significance for later phases of the project, for which DMJMH+N was ultimately engaged. ${ }^{100}$ At the outset of the initial effort, Taylor had been unwilling to accept the disputed provisions because he was concerned, presciently as it turned out, about setting an unacceptable precedent for contracts for future efforts. ${ }^{101}$

The difficulty of specification of contract obligations is even more starkly present in film production, which is similar to construction projects in using temporary, ad hoc teams for finite, relatively short-term efforts. When a studio agrees with a producer to finance the production of a feature film, it will almost

99. See supra note 71. Compare the following excerpt from Steven Kelman, writing about U.S. government procurement of computer systems:

How can the government predict from a written proposal the zeal a vendor will display in solving an unexpected problem? How can the government tell from a written proposal how successfully a vendor weeds out incompetent repair people and motivates the others to fix things efficiently and properly? How can the government determine from a written proposal whether the vendor plans to assign nine lawyers to comb the contract in search of ambiguities to exploit after the contract is signed?

What normal people in their everyday lives do when faced with such a situation is to rely on the main source of available information besides search-namely, experience.

Steven Kelman, Procurement and Public Management 39 (1990).

100. Among other issues arising at a later contracting phase, SJHC wanted DMJMH+N to guarantee a maximum price for the construction project that it was to design, a guarantee that Taylor found excessively onerous.

101. Taylor made the interesting observation that a client who is "unyielding" on contract provisions is the kind of client who is likely to "come after you" later-in which case the provisions could turn out to be important. Thus, Taylor pays attention both to the substantive effect of contract terms and to the signals the other side sends in negotiation. Compare Dent, Jr., supra note 10 , at 69 ("When cooperation falters, partners dust off and read their contract. ...").

Even without a signed agreement, and even with an impasse over certain terms, the parties did have an oral contract; they had agreed on basic terms. Cf. Stewart Macaulay, supra note 16, at 60 ("Even when a purchase order and acknowledgement have conflicting provisions printed on the back, almost always the buyer and seller will be in agreement on what is to be sold and how much is to be paid for it."). Similarly, it is commonplace in film production that the lawyers will bargain hard over terms and then the parties will not sign the final product. This leaves room for later haggling and even for failing to abide by agreed-upon terms, but there remain basic terms that cannot be ignored without a serious blow to reputation, in an industry in which reputation as to such matters is of vital importance. Macaulay puts it this way: "Although the parties fail to cover all foreseeable contingencies, they will exercise care to see that both understand the primary obligation on each side." Id. at 62 . Macaulay later describes the non-legal sanctions, of which "the most obvious" is concern for "general business reputation." Id. at 63. 
invariably condition its obligation on its approval of (a) the script, (b) the director, (c) the principal cast, and (d) the budget and shooting schedule. ${ }^{102}$ From the very start, however, all the elements are interrelated and changeable. The director may want changes in the script. Political events may occur that necessitate a change in the script or in locations. The lead actor may object to aspects of the script or the choice of other actors. Changes in the script, both before and after shooting begins, may require changes in the schedule or the budget or both. All these types of changes, and more, are not only possible but likely. Thus, a completely specified contract between the studio and the producer is literally impossible. Even though the lawyers for the producer and the studio often spend endless hours bargaining over the terms of a contract, often it is not signed by the parties, ${ }^{103}$ and even if it is, often it is ignoredthough with two general exceptions. First, generally the studio will not renege on the terms relating to the money it is required to pay to the producer and certain other participants. Second, the studio is likely to respect agreements as to entitlement to credits (which are of far more importance to the participants than those outside the industry might imagine).

Thus, both in construction and in film production trust or good faith, backed by reputational concerns, is essential. ${ }^{104}$ Trust reduces the importance of specification. At the same time, the lack of specification in these settings should not be overemphasized. Efforts to specify obligations reduce the

102. Interview with Kenneth Ziffren, Ziffren, Brittenham, Branca, Fischer-Lurie \& Stiffelman, LLP, in Beverly Hills, Cal. (Jan. 18, 2003). Mr. Ziffren has long been widely recognized as one of the leading specialists in entertainment law.

103. There are, however, certain documents that must be signed: (a) those that must be signed by the writer, and probably also the director and the producer, giving the studio a valid copyright; and (b) documents required for bank loans; and (c) an agreement on the budget for the benefit of the completion guarantor.

By way of contrast, in the production of movies for television, there is far less uncertainty. This observation was offered to co-author W. Klein by David R. Ginsburg, a long-time, successful producer of such movies (and earlier a practicing lawyer in the entertainment industry) during an interview in Santa Monica, on January 23, 2003. Ginsburg noted that contractual relations for producing TV movies are different from contracting relationships for feature films because TV movies are produced more quickly and on much lower budgets. With TV movies it is the firm expectation that the budget agreed upon (along with the writer, major cast, etc.) by an independent producer, on one side, and the network buyer and the distributor, on the other side, will not be exceeded. It is the responsibility of the producer to ensure that the budget is not exceeded. The producer bears the cost when the budget is exceeded and rarely will there be any additional payment for unforeseen budget excess-though if the producer fails to deliver a finished product after having received advances, and the production firm becomes bankrupt, the network and the distributor will bear the loss. Directors of TV movies who cannot be relied upon to respect the budget will not find work. For feature films, the directors are often more powerful and are given much more freedom to make changes that result in breaking the budget. Thus, contractual obligations, both explicit and implicit, are clearer and are perhaps more important to the parties for TV movies than for feature films.

104. Compare this statement in the government's request for proposals for reconstruction of the Pentagon: "Trust that each partner [the government and the contractor] will act in accordance with [previously stated general] expectations is essential to maintaining the relationship that will enable this contract to succeed." Public Release Version of the Pentagon Renovation Wedges 2-5 Request for Proposal 3 (2001) (on file with authors). Cf. Dent, Jr., supra note 10, at 65-70, 80-83. 
pressure on trust by reducing the chances of misunderstanding. ${ }^{105}$ Indeed, even when there is full recognition that circumstances will likely change in unanticipated ways and there is no expectation that the contracts will be signed, there may be lengthy discussions about the obligations on either side, often resulting in detailed documents. For example, in film production, there is a budget that serves, at the very least, as a guidepost for what the studio is entitled to expect and what the producer can be expected to deliver, as well as specification of payments to be made that is highly likely to be respected. Similarly, even though it was impractical to specify level of effort, skill, and creativity, and even though the contract was not signed, SJHC and DMJMH+N did have a clear understanding of the deliverables that SJHC was entitled to expect.

\section{E. Contracts, Fees, and Incentives}

All the consultants were hired for fixed fees. One question that this raises is, why were the consultants not hired at an hourly rate, the method of compensation most common for legal services? Since it was difficult to specify the quality of the services expected, and the time to be devoted to the project, an hourly rate might seem, superficially at least, to be a sensible approach (especially in a setting characterized by high levels of trust and effective reputational sanctions).

In our case, SJHC had a limited budget. The problem thereby presented could have been solved by using an hourly rate with a maximum amount (a "cap"), but the general perception seems to be that the maximum will then turn out to be the contract amount. ${ }^{106}$ Moreover, it was possible within reasonable

105. Put another way, people can do business on the basis of trusted relationships or on the basis of enforceable agreements, or, as in construction, on the basis of some combination of the two, with each supporting the other. Compare Lucie Cheng \& Arthur Rosett, Contract with a Chinese Face: Socially Embedded Factors in the Transformation from Hierarchy to Market, 1978-1989, 5 J. CHINESE L. 143, 188 (Fall 1991): ("Contract suggests a safer way to do business with strangers [compared with doing business with family, clans members, etc.], who, lacking authority or relational sanctions for performance and security, depend heavily on the legal sanctions provided by contract law.') Cheng and Rosett later observe: "The heartland of Contract is the band of transactions that are made between nearstrangers." Id. at 154. While the introduction of enforceable contracts has been important to economic development in China, the introduction of the idea of trustworthy relationships is important to understanding economic transactions and organization in America. See Margaret M. Blair \& Lynn A. Stout, Trust, Trustworthiness, and the Behavioral Foundations of Corporate Law, 149 U. PA. L. REV. 1735, 1806 (2001) (participants in closely held corporations may avoid specification for fear of undercutting mutual trust, but specification "may avoid the sort of nasty surprises that undermine trust in a long-running relationship"). For discussion on the role of trust, and its relationship to specifications, in strategic alliances, see George Dent, Lawyers and Trust in Business Alliances, 58 THE BUS. LAWYER 45 (2002); George Dent, The Role of Lawyers in Strategic Alliances, 53 CASE W. RES. L. REV. 953 (2003).

106. The legal services, however, were billed on an hourly rate. Klein anticipated that legal work on the legal "entitlement" from the City might be done for a fixed fee. It may be that Klein assumed it would be easier to estimate the amount of time that such work would be likely to take than to estimate the amount of time to negotiate and draft the development agreement. 
tolerances for the architects to estimate how much time they would need. ${ }^{107}$ There had been a competition for the job, and Mike Russell, representing $\mathrm{SJHC}$, had enough experience to know whether the contract amount was reasonable. Though all the consultants (including the feasibility consultants) worked for fixed fees, there may have been particularly strong reasons for a fixed fee for the architects. According to Taylor, architects are never content to treat a design as finished; they can always imagine another approach or another improvement. It is in their nature. The fixed fee, along with their need to make a living, forces finality. ${ }^{108}$

There was always the possibility of additional fees for services not initially contemplated and described in the contract. ${ }^{109}$ Such additional fees would,

107. This may be the best explanation for why, by contrast, lawyers still work, mostly, for hourly fees. Lawyers will insist, probably with good reason, that they simply cannot anticipate all contingencies. As Joel Rabinovitz (long-time practitioner at a large firm and former UCLA colleague) pointed out to us, even when a lawyer is asked to form an LLC for a couple of business clients, he or she cannot predict what issues will be raised and how much time it will take to resolve them. In a matter such as a merger the difficulty of estimation becomes more severe. At the outset, the lawyer will not be able to predict with any accuracy the amount of time that will be needed for negotiation and drafting, which will depend in large part on the stance taken by the other side. A due-diligence inspection of the client's books and records may turn up various problems. Regulatory agencies may take positions or make demands that cannot be anticipated, and so forth. Thus, compared with construction work, the story is that legal work may involve far greater uncertainty in estimating the services that will be required, which may explain why hourly rates are typical for lawyers while cost-plus contracts are relatively less common in construction. It would, of course, be possible to shift the risk of uncertainty from the client to the lawyer. This is the effect of a fixed fee. But that might create unacceptable incentives to limit effort-incentives that lawyers, more so than architects, might find hard to resist.

It is interesting that, despite the uncertainty in the amount of time that they will need to devote to a matter, investment bankers generally work on what amounts to a fixed, and contingent, fee. The investment bankers figure that they make more money this way than with an hourly or per diem rate. See Eccles \& Crane, supra note 59, at 39. Lawyers representing clients with personal injury claims, generally for contingent fees, no doubt have arrived at much the same conclusion. In each case relative risk aversion of client and professional may have something to do with these practices. Perhaps more significant is that personal injury lawyers and investment bankers have multiple engagements and are therefore better able than their clients to reduce overall risk.

108. This protects the client's interests while at the same time giving the administrators within the architectural firm a lever for forcing individual architects to bring projects to a conclusion.

109. This would be like the well-known change order in connection with a fixed-price construction contract. There are two classic types of construction contracts: (1) fixed price, within a process described as design-bid-build and (2) cost-plus. See Sweet, supra note 4, at 322. An hourly rate contract is analogous to a cost-plus contract. For a rigorous analysis of the essential differences between the two basic types, see Patrick Bajari \& Steven Tadelis, Incentives Versus Transaction Costs: A Theory of Procurement Contracts, 32 RAND J. ECON. 387 (2001). Bajari and Tadelis offer the following conclusion:

On one hand, FP [fixed price] contracts provide the strongest incentives for cost reduction. On the other hand, if the design is left incomplete, then the cost of renegotiating FP contracts [through the change-order process] is high. When $\mathrm{C}+$ [cost-plus] contracts are used the costreducing incentives disappear, but the process of adaptation is far smoother because the reimbursement process is simple, well defined, and leaves little room for haggling. Id. at 404.

The preferred type of contract will also depend on the feasibility of specification and on the ability to monitor. A fixed-price contract is consistent with ease of specification, with predictability, and with ease of monitoring. Such conditions are also supportive of outsourcing (that is, contract as opposed to hierarchy). When specification is difficult-as it is almost invariably on a major construction project-the general contractor is forced to make a lot of guesses. Raising the bid price to take account of 
however, be unusual. Paul Danna, of DMJMH+N, noted that clients hate requests for additional fees. He added that his firm, unlike some other firms, had a reputation (which he valued) for rarely requesting such fees. ${ }^{110}$ On the other hand, Rusty Doms said that if more time and effort were needed than was expected, and the contractor asked for money, he would want to "sit down and talk about it." His view, which seems to be common among people in business, is that a "contract has to be fair to both sides."111

contingencies is likely to result in loss of the contract. For the low bidder, the profit will generally have to come from change orders. With a cost-plus contract the financial incentive for the contractor to hold down costs is weak, but commitment to fairness and quality of performance, plus a concern for reputation may protect the owner/client.

In recent years, intermediate forms of contracting-mostly variations of the so-called design-build contract-have been developed in an attempt to preserve incentives for cost saving (and design improvement) while at the same time reducing haggling and other "transaction" costs. Under such contracts construction can begin before the design is completed, which obviously speeds up the process. Moreover, contractors can lend their expertise to the design effort. For example, the architect/engineer might specify the delivery of a certain volume of air to an area and leave it to the contractor to determine the size of the ducts. "One of the main advantages of the design-build process is the single-point responsibility of the design-builder for both design and construction problems." Adrian L. Bastianelli, III, Notes from the Editor: Design-Build, 21 CONSTRUCTION LAW. 3 (Winter 2001). For good brief descriptions of various forms of contracting, see Christopher M. Gordon, Choosing Appropriate Construction Contracting Method, 120 J. Construction EngINEERING AND MGMT. 196 (1994); 3D/International, Project Delivery Strategy, (unpublished essays), available at http:/www.3di.com (only available on Internet Explorer, not on Netscape) (last visited Jan. 14, 2003); Philip L. Bruner, Design-Build Viewed from the Surety's Perspective, 20 CONSTRUCTION LAW. 17 (July 2000); Mark C. Friedlander, Designer-Led Design-Build: Why It Works for Contractors, 21 ConstruCTION LAW. 29 (January 2000); Christopher L. Noble, The Design-Builder-A/E Contract: A Comparison of Standard Forms, 21 CONSTRUCTION LAW. 5 (Winter 2001). A similar process to design-build has arisen in manufacturing. See Michael Hammer, The Superefficient Company, HaRvard BUS. REV., Sept. 2001, at 88. For discussion regarding incentive provisions in contracts for highway construction, see David Arditti et al., Incentive/Disincentive Provisions in Highway Contracts, $123 \mathrm{~J}$. ConstRUCTION ENGINEERING \& MGMT. 302 (1997) (payments per day of completion ahead of schedule); David Arditti \& Finuzan Yasamis, Incentive/Disincentive Contracts: Perceptions of Owners and Contractors, $124 \mathrm{~J}$. CONSTRUCTION ENGINEERING AND MGMT. 361 (1998).

Another interesting variation is the cost-plus-fixed-fee contract, under which "the firm's profit allowance is fixed rather than being proportional to actual costs." Stefan Reichelstein, Contracting Incentive Schemes for Government Contracts: An Application of Agency Theory, 67 ACCT. REV. 712 (1992). Moreover, "[i]n recent years, there has been an increasing trend in the United States to provide positive incentives for cost control by using cost-plus-incentive-fee contracts" though these confront the problem that often "the government is unable to formulate realistic cost targets." $I d$.

Perhaps the most interesting variation is the Award Fee Plan used in contracting for renovation of the Pentagon, under which the contractor on a cost reimbursement contract was guaranteed neither fee nor profit. Instead, fees were to be awarded based on a complex spreadsheet analysis applying a detailed set of performance criteria and a plan for administration of the award process. See Public Release Version of the Pentagon Renovation Wedges 2-5 Request for Proposal 3 and $\S \mathrm{C}$ at 59-61 (2001) (on file with authors). The contract states that 'if the Government is greatly pleased with the Contractor's performance the Contractor will be greatly pleased with the Government's reward. The converse is obviously true as well." Id.

110. Similarly, in construction, some general contractors have a (bad) reputation for bidding low and making their profit on change orders. See supra note 109 (discussing lowest bid). In the presence of this phenomenon, reputation is important, and one architect (not involved in the SJHC project) said that his firm advised clients never to contract with the lowest bidder. Or, as stated by Joseph Scarano, "the worst form of contract[ing] is the low bid." There is, nonetheless, an inevitable correlation between the fixed-fee contract and the need for change orders.

111. In deciding whether additional compensation might be fair, Doms would want to know why the extra effort was unexpected, why it is needed, etc. The outcome would also, he said, depend on 
To many observers, including the authors of this study, the fixed-fee contracts seem to present a problem of incentives. Given that quality was not subject to specification and that better quality would mean more work, what incentive was there to do more than a bare minimum? When the team members were asked about this issue, however, their reaction for the most part was what might best be described as puzzlement, as if it simply had not occurred to them that they might fail to deliver high-quality services. When pressed, they talked about the effect of performance on reputation and on future work, but at the same time made clear that they took pride in their work and were personally committed to doing as good a job as they could. ${ }^{112}$ This reaction could, of course, be attributed to concern for reputation and its effects on future earnings. On further pursuit of the issue, the team members expressed their recognition that this was important. Yet they also conveyed the impression that there was more to it than simply a concern for reputation, that their performance was a matter of personal pride and commitment. ${ }^{113}$

An hourly rate would, of course, present a different incentive problemnamely, a lack of incentive to limit the number of hours and to work efficiently. In construction, in the actual building phase, the counterpart to the hourly rate is the cost-plus contract - that is, a contract in which the supplier of the services is compensated for all costs and receives a percentage of the costs as its fees. As one might imagine, this gives rise to the risk of inefficient performance. ${ }^{114}$

whether he thought the contractor had been doing a good job. See also In re Staples, Inc. Shareholders Litigation, 2001 WL 640377 (Del. Ch.), *17 ("Presumably Staples has an interest in ensuring that its employees and managers who bought Staples.com options feel that they have been treated fairly."); Jolls et al., supra note 71 , at $1489-97$ (people want to be fair and are willing to incur costs to punish what they perceive to be unfaimess); Thomas Kem et al., The Winner's Curse in IT Outsourcing: Strategies for Avoiding Relational Trauma, 44 CAL. MGMT. REV. 47, 56 (2002) (renegotiation of a contract that a client concluded was not fair to its supplier). For more on the importance of faimess and reciprocity and the resultant efficiency gains in contractual relations characterized by these features, see Ernst Fehr \& Simon Gächter, Fairness and Retaliation: The Economics of Reciprocity, 14 J. ECON. PERSP. 159, 162 (2000); Ernst Fehr et al., Reciprocity as a Contract Enforcement Device: Experimental Evidence, 65 ECONOMETRICA 833, 833 (1997); Matthew Rabin, Incorporating Fairness into Game Theory and Economics, 83 AM. ECON. REV. 1281 (1993).

112. Mike Russell spoke of his "fear of not doing a good job," for his own sense of who he is and what he wants to be. A similar thought was expressed to co-author W. Klein by David R. Ginsburg, a successful producer of movies, mostly for television where the payment for the product is essentially a fixed fee (with minor incentive features). Ginsburg, when asked about his incentives, stated, quite convincingly, that he was "committed to making good, well-crafted movies," largely as a matter of "personal pride" and "professionalism." He added, "by the way, if you produce bad movies you won't last long."

113. Doms was working without any expectation of financial return (even indirectly), as was coauthor W. Klein. In a conversation, Doms and W. Klein shared the thought that they were both retired (from their paying jobs) but were doing what they liked to do, and it was at least implicit that neither of them would have wanted to do a half-hearted job. The concept of personal "commitment" and its role in economic behavior is nicely discussed in Amartya K. Sen, Rational Fools: A Critique of the Behavioral Foundations of Economic Theory, in BEYOND SELF-INTEREST Ch. 2 (Jane J. Mansbridge, ed.,1990).

114. See supra notes 109-11. 


\section{F. Who Selects Team Members?}

$\mathrm{SJHC}$ hired the DMJMH+N architects, who in turn brought in the landscape architects and the residential architect-who were by no means minor players. But SJHC hired the civil engineer and the traffic consultant. It was not content to allow the DMJMH+N team to do this. Part of the reason is simply that the key people at SJHC (Klein, Russell, and Doms) had the ability to choose-they were able to identify the people they wanted and had confidence in them, based on reputation and past experience. Another reason is that civil engineering and traffic issues affected the entire SJHC development, both Phase I and Phase II, and were vital to overall, long-term success.

This may be comparable to recent developments in law practice, with the general counsel of the client corporations selecting different lawyers (and their law firms) for different functions, even for a single project, but with the lawyers then putting together their teams.

By way of comparison, the selection of production teams in the motion picture industry follows a similar pattern that may be more obvious and easier to understand. Imagine an independent producer who has developed an idea for a film and has a first-draft script. He or she approaches a studio, seeking financing. Suppose the studio likes the producer's script and agrees to provide financing. Typically, the producer will want to choose the screenwriter, the director, and the principal cast, and will be principally, or at least initially, responsible for doing so. As previously noted, however, the studio will almost invariably insist that his selections be subject to its approval. The studio will also insist on the right to approve, or disapprove, the final script and the budget and shooting schedule. Its money is at risk, and with risk goes control. Thus, the producer and the studio executives will engage in a joint decision-making process for selection of the participants, changes in the script, and setting the budget and shooting schedule. The principal cast members, the writer, and the director may also have suggestions, or demands, that become part of the selection, budget-setting, and scheduling process. Once the principal participants are selected, they select other participants. For example, the director is likely to have a crew of assistants with whom he or she likes to work, and a camera person. The producer will be consulted but is likely to accept the director's recommendations for these additional participants, subject to budget constraints (which may bring the studio back into the selection process). There may be further delegation of selection of the members of the production team. For example, the camera person will select his or her assistants and crew. There are, however, two members of the production team who are important to the protection of the studio's interests and who will be hired by the studio. The first is the production auditor. The second is the unit production manager, or UPM. The UPM chooses and supervises the carpenters and set builders, negotiates for locations, etc. The UPM thus protects the studio 
from waste, excessive cost, skimming, and padding. ${ }^{115}$

\section{G. The Role of Law, Lawyers, and Legal Educators}

Experienced practitioners are sensitive to the risk that focusing excessively on difficult organizational issues and engaging in hard bargaining on behalf of clients may undermine trust and cooperation and spoil a deal. ${ }^{116}$ Moreover, as observed in the present study, clients may, quite rationally and sensibly, be willing to do business without signing a contract, though with mutual understanding about basic obligations. These types of considerations receive scant attention in the basic law curriculum, which may train students to be far more aggressively adversarial than is consistent with good transactional lawyering. ${ }^{117}$

The present study also suggests that the default rules provided by formal organizational law (e.g., the law of corporations or partnerships) may fit awkwardly with the reasonable expectations of the parties. Partnership law, for example, imposes strong fiduciary obligations on partners, while the good-faith

115. This account is based on the interview with Kenneth Ziffren, referred to in supra note 102.

116. The same point has been made with respect to the lawyer's role in big-time strategic alliances. See generally, Symposium, The Role of Lawyers in Strategic Alliances, 53 CASE W. L. REV. 857-976 (2003). At an earlier symposium, Lee Buchheit offered a similar observation with respect to transactional lawyering at big Wall Street firms, stating:

You hire a corporate lawyer to negotiate a transaction for you; that is almost by definition the beginning of a business relationship between the two principals. Litigation, however, is the end of a business relationship. A corporate lawyer's behavior, in the context of the negotiation, reflects upon his or her client. And if the corporate lawyer comes across as grasping, gratuitously aggressive, or uncreative or unreasonable, all of that can poison the business relationship that their client and the other party are about to enter into. Sometimes you walk out of a negotiating room and your client says, "When this transaction ends I don't ever want to ever see these people again." If that disappointment is caused by the behavior of the other side's lawyer during the negotiations, has that lawyer really helped his client? On the other hand, if you're at the litigation stage, you're probably not looking forward to a bright future with the other side. For that reason, you're prepared to tolerate a little more of the gladiatorial instinct in your counsel.

Symposium, Theory Informs Business Practice, 77 CHI-KENT L. REV. 121, 140 (2001). See also Claire A. Hill, A Comment on Language and Norms in Complex Business Contracting, 77 CHI.-KENT L. REV. 29 (2001) (observing that contracts in complex business transactions perform a "stage setting" role for the relationship, where "accommodation is more the rule than the exception").

In an interview over lunch when we were in the early stages of this project, Ken Ziffren made the same point about effective transactional lawyering in the entertainment industry. (Interview at the UCLA Faculty club, Feb. 22, 2001).

117. See George Dent, The Role of Lawyers in Strategic Alliances, 53 CASE W. RESERVE L. REV. 953 (2003). Dent explains:

And what happens when students arrive at law school? Almost all first year courses are litigation oriented. And even to the extent that one encounters transactional courses in law school, there is still a tendency to be suspicious and say: "Watch out. The other side is probably trying to take advantage of you, so be careful. And, of course, bargain hard for your client, get the best possible deal you can." So, it is not surprising that when students emerge from law school and go into practice, they are bewildered by a client who says, "We are trying to cultivate a relationship of trust and confidence here, and everything you are doing is destroying that."

ld. at 962 . 
obligations of parties to a contract are far weaker. ${ }^{118}$ Yet relationships of trust were a crucial element of the teams in our study, even though there was not even a contractual relationship, much less a partnership, among the team members. At the same time, it is easy enough to think of law firms, organized as partnerships, in which there is a significantly lesser sense of mutual obligation.

These observations raise a number of questions that we do not pursue. One such question is whether the marginality of law is a general phenomenon in transactional lawyering or the result of idiosyncratic characteristics of the construction industry, with its high levels of uncertainty and the relatively short duration of projects. Another such question is, to what extent is the role of trust dependent on a strong set of rules and enforcement mechanisms that are taken for granted?

\section{H. Duration, Specification, and Control}

$\mathrm{SJHC}$ hired $\mathrm{DMJMH}+\mathrm{N}$ for a limited project, but there was the possibility that $\mathrm{DMJMH}+\mathrm{N}$ would later be hired for subsequent phases-which is what eventuated. The short initial term gave SJHC more control ${ }^{119}$ and provided a strong incentive to DMJMH+N. Moreover, the relatively short term reduced problem of specifying the task, pending the development of more information.

Duration, therefore, can operate as both a substitute for the control that one would obtain in a traditional hierarchical firm and as a solution to the problem of specification.

\section{CONCLUSION: STEPPING BACK}

The question of why certain productive activity occurs inside firms and other activity occurs across markets has been the subject of extensive inquiry in law and economics. The standard explanation that derives from the work of stalwarts such as Coase and Williamson has to do with transactions costs. The firm, with its hierarchical structure and power of fiat, serves to solve problems of, among other things, opportunism, hold ups, team production, and specialization. ${ }^{120}$ Underlying these ideas is the problem of uncertainty or, put differently, the difficulty of specifying contacts that cover every important

118. The fiduciary obligations of partners supposedly enhance and protect the pre-existing relationships of trust that exist among partners. The classic case on the subject is Meinhard v. Salmon, 249 N.Y. 458 (1928). For an argument that fiduciary duties operate to make trust "rational," see Lawrence E. Mitchell, The Importance of Being Trusted, 81 B.U. L. REV. 591, 614-16 (2001). But see Ribstein, supra note 71, at 556 (arguing that "law cannot produce trust").

119. See William A. Klein \& JOHN C. COFfEe, JR., Business ORganization and FinanCE 17, 25-26 (8th ed. 2002).

120. For a description of the various theories of the firm and their evolution, see William $W$. Bratton, Jr., The New Economic Theory of the Firm: Crivical Perspectives from History, 41 STAN. L. REV. 1471, 1474-1501 (1989). 
contingency. Whatever the theory, the central theme is that the firm houses and controls production.

Contrary to the standard story, in construction (and elsewhere to varying degrees) production takes place outside the firms with which the production team members were affiliated. This did not mean that firms did not exist in a meaningful way. ${ }^{121}$ They did, but instead of housing production, they housed functions such as monitoring, networking, marketing, accounting, and insurance. Given the standard story about uncertainty, one might have expected that the tasks to be performed in construction are characterized by low uncertainty and an ease of specification-for example, that the plans for a building could fully specify what needs to be done to meet the client's expectations. In fact, construction planning prior to groundbreaking is characterized by considerable difficulty of specification.

Of far more salience are attributes of construction that one might expect to find in many other settings-namely, valuable relational/informational networks, a mosaic of contractual relationships, and a culture of collaboration that depends on trust, commitment, and reputation.

121. In recent years, given the high levels of outsourcing in industries such as high tech, a number of scholars (including us) have questioned the continued value of the iraditional concept of the firm (and related constructs of hierarchy and a nexus). See, e.g., Gulati et al., supra note 82, at 887; Douglas G. Baird, In Coase's Footsteps 14 (January 2003) (Olin Law \& Economics Working paper No. 175), available at ssrn.com/abstract id=368400. Others, such as our colleague Steve Bainbridge, have vigorously argued the continued importance of these concepts. Stephen M. Bainbridge, The Board of Directors as a Nexus of Contracts, 88 lowA L. REV. I (2002). The discussion in the text perhaps suggests the need for a different focus-that is, on the question: What do firms do these days? This latter question is the focus of the recent article by Baird and Rasmussen, where they ask whether firms, given what they do these days, need to be preserved as going concerns. Douglas G. Baird \& Robert Rasmussen, The End of Bankruptcy, 53 STAN. L. REV. 751 (2003). Lynn LoPucki vigorously challenges the factual premises on which Baird and Rasmussen base their conclusions about the role of the law of insolvency reorganization. Lynn LoPucki, The Bankruptcy Boom: A Challenge to Baird and Rasmussen's The End of Bankruptcy (2003) (unpublished manuscript, on file with author W. Klein). 